\title{
Distal gene regulation mediated by non-coding RNAs contributes to germline risk for
} breast and prostate cancer

Nolan Cole ${ }^{1}$, Paige Lee ${ }^{2}$, Tommer Schwarz ${ }^{3,4}$, Pan Zhang ${ }^{5}$, Matthew L. Freedman ${ }^{6,7}$, Alexander Gusev $^{6}$, Sara Lindström0,11, Michael J. Gandal ${ }^{5,12,13}$, Bogdan Pasaniuc ${ }^{4,12,13}$, Arjun Bhattacharya ${ }^{4,14 *}$

1. Department of Statistics, Brigham Young University, Provo, UT, United States

2. Department of Statistics, University of California, Los Angeles, CA, United States

3. Bioinformatics Interdepartmental Program, University of California, Los Angeles, CA, United States

4. Department of Pathology and Laboratory Medicine, David Geffen School of Medicine, University of California, Los Angeles, CA, United States

5. Department of Psychiatry, Semel Institute, David Geffen School of Medicine, University of California, Los Angeles, CA, USA

6. Department of Medical Oncology, The Center for Functional Cancer Epigenetics, Dana Farber Cancer Institute, Boston, MA, USA

7. The Center for Cancer Genome Discovery, Dana Farber Cancer Institute, Boston, MA, USA

8. Program in Neurobehavioral Genetics, Semel Institute, David Geffen School of Medicine, University of California, Los Angeles, CA, USA

9. Department of Human Genetics, David Geffen School of Medicine, University of California, Los Angeles, CA, USA

10. Department of Epidemiology, School of Public Health, University of Washington, Seattle, WA, USA

11. Public Health Sciences Division, Fred Hutchinson Cancer Research Center, Seattle, WA, USA

12. Department of Human Genetics, David Geffen School of Medicine, University of California, Los Angeles, CA, USA

13. Department of Computational Medicine, David Geffen School of Medicine, University of California, Los Angeles, CA, USA

14. Institute of Quantitative and Computational Biosciences, David Geffen School of Medicine, University of California, Los Angeles, CA, USA

*Corresponding author: Arjun Bhattacharya (abtbhatt@ucla.edu) 
medRxiv preprint doi: https://doi.org/10.1101/2022.02.08.22270601; this version posted February 23, 2022. The copyright holder for this preprint (which was not certified by peer review) is the author/funder, who has granted medRxiv a license to display the preprint in perpetuity.

It is made available under a CC-BY 4.0 International license .

\section{ABSTRACT}

Genome-wide association studies (GWAS) have identified numerous genetic loci associated with breast and prostate cancer risk, suggesting that germline genetic dysregulation influences tumorigenesis. However, the biological function underlying many genetic associations is not well-understood. Previous efforts to annotate loci focused on protein-coding genes (pcGenes) largely ignore non-coding RNAs (ncRNAs) which account for most transcriptional output in human cells and can regulate transcription of both pcGenes and other ncRNAs. Though the biological roles of most ncRNAs are not well-defined, many ncRNAs are involved in cancer development. Here, we explore one regulatory hypothesis: ncRNAs as trans-acting mediators of gene expression regulation in non-cancerous and tumor breast and prostate tissue. Using germline genetics as a causal anchor, we categorize distal (>1 Megabase) expression quantitative trait loci (eQTLs) of pcGenes significantly mediated by local-eQTLs of ncRNAs (within 1 Megabase). We find over 300 mediating ncRNAs and show the linked pcGenes are enriched for immunoregulatory and cellular organization pathways. By integrating eQTL and cancer GWAS results through colocalization and genetically-regulated expression analyses, we detect overlapping signals in nine known breast cancer loci and one known prostate cancer locus, and multiple novel genetic associations. Our results suggest a strong transcriptional impact of ncRNAs in breast and prostate tissue with implications for cancer etiology. More broadly, our framework can be systematically applied to functional genomic features to characterize genetic variants distally regulating transcription through trans-mechanisms.

\section{SIGNIFICANCE}

This study identifies non-coding RNAs that potentially regulate gene expression in transpathways and overlap with genetic signals for breast and prostate cancer susceptibility, with implications for interpretation of cancer genome-wide association studies. 
medRxiv preprint doi: https://doi.org/10.1101/2022.02.08.22270601; this version posted February 23, 2022. The copyright holder for this preprint (which was not certified by peer review) is the author/funder, who has granted medRxiv a license to display the preprint in perpetuity.

It is made available under a CC-BY 4.0 International license .

\section{INTRODUCTION}

Genome-wide association studies (GWAS) of cancer risk have revealed risk-associated alleles at hundreds of genetic loci, with breast and prostate cancer GWAS yielding the largest number of associations $(1,2)$. Through integration with transcriptomic and functional genomics datasets, the proposed target genes for many of these risk loci have been found in protein-coding regions of the genome (1-4). However, many risk variants fall in non-coding regions of the genome and, for these variants, identifying the likely biological mechanism is challenging. One proposed mechanism for GWAS-identified risk variants is trans-acting pathways: a GWAS variant affects a regulatory feature, like a transcription factor, in proximity, which then affects genes located far away from the GWAS variant. Particularly, one study identified GWAS risk variants for breast cancer that confer trans-effects through transcription factors, like ESR1, MYC, and KLF4 (5). Another potential mechanism by which GWAS variants in non-coding regions affect risk is mediation of trans-acting effects of genetic variants through non-coding RNAs (ncRNAs).

Although ncRNAs do not code for proteins, they account for nearly $60 \%$ of transcriptional output in human cells and interact with a complex network of genes, transcripts, and proteins with widespread effects on cell biology $(6,7)$. Some ncRNAs, like microRNAs (miRNAs), target and degrade mRNA transcripts of specific genes and link to regulatory networks that include multiple ncRNAs and protein-coding genes (pcGenes). These complex interactions between ncRNAs and pcGenes support the hypothesis that ncRNAs have key roles in cellular pathways $(6,8,9)$. Specific ncRNAs have been shown to leave their transcription site and regulate gene expression at genomic regions far from their transcription start site $(8,9)$. However, regulatory impacts of ncRNAs on transcription of pcGenes are generally uncategorized, especially in a systematic fashion (8). 
medRxiv preprint doi: https://doi.org/10.1101/2022.02.08.22270601; this version posted February 23, 2022. The copyright holder for this preprint (which was not certified by peer review) is the author/funder, who has granted medRxiv a license to display the preprint in perpetuity.

It is made available under a CC-BY 4.0 International license .

ncRNAs have shown associations with the onset and progression of different cancers, are enriched in multiple tumor types, and are even therapeutic targets, as they act as regulators of genes in important tumorigenic or progressive networks (10). For example, the long ncRNA XIST exerts oncogenic and metastatic effects in multiple cancer types (11). Profiling and deep sequencing of ncRNAs have shown that perturbing ncRNA biogenesis affects amplification, deletion, and normal epigenetic and transcriptional regulation (10,12-14); accordingly, ncRNAs can act as oncogenes or antagonize tumor suppressors.

However, as most ncRNA mechanisms in cancer tumorigenesis or progression have been categorized on a case-by-case basis $(13,14)$, mechanistic impacts of ncRNAs have not been explored systematically. Bioinformatics analyses that leverage high-throughput genomics have investigated the role of ncRNAs through computational target prediction or differential expression analyses. Although these computational methods have elucidated potential roles of ncRNAs in cancer, they have limitations, including computational feasibility and functional translation of sequence similarity methods (15) and reverse causality for differential expression analyses (i.e., differential expression more likely reflects consequences of disease) (16).

One systematic approach to identifying potential trans-mechanisms of regulation is to use genetic variants as causal anchors. A prevailing thought is that distal expression quantitative trait loci (eQTLs) of genes, where the genetic variant is far away from the gene (more than 1 Megabase, or Mb), are often themselves local-, or cis-acting, QTLs of a regulatory feature (1722). We emphasize that the modifiers "local" and "distal" refer merely to distances in the genome (i.e., within or outside $1 \mathrm{Mb}$, respectively), whereas cis- and trans-acting refer to the biological mechanism (i.e., direct or indirect interaction, respectively). Molecular features, like ncRNAs, that have potential trans-acting regulatory effects can be identified through mediation analyses, either at variant- or gene-level $(18,21,23,24)$. Not only can these analyses point to 
medRxiv preprint doi: https://doi.org/10.1101/2022.02.08.22270601; this version posted February 23, 2022. The copyright holder for this preprint (which was not certified by peer review) is the author/funder, who has granted medRxiv a license to display the preprint in perpetuity.

It is made available under a CC-BY 4.0 International license .

distal relationships between ncRNAs and pcGenes, but they can point to genetic variants associated with disease etiology with potential distal effects in the transcriptome.

Here, we systematically map distal-eQTLs of pcGenes that are potentially mediated by localeQTLs of ncRNAs in non-cancerous and tumor prostate and breast tissue, using data from the Genotype Tissue-Expression (GTEx) Project (25) and The Cancer Genome Atlas (TCGA) (26). We then employ colocalization (27) and genetically-regulated expression analysis (28) to identify overlaps in eQTLs and GWAS signals for both overall and molecular subtype-specific breast (2) and overall prostate (1) cancer risk. In total, our work shows the widespread transcriptomic impact of genetically-mediated portion of ncRNAs and that this impact has key associations with cancer susceptibility. This approach provides a rigorous framework to not only categorize functional hypotheses of distal regulatory effects of ncRNAs but also other regulatory molecular features.

\section{MATERIALS AND METHODS}

A graphical representation of our methods is provided in Supplemental Figure S1.

\section{Data acquisition and processing}

We used pre-processed genotype, transcriptomic, and covariate data for non-cancerous mammary and prostate tissue from the Genotype-Tissue Expression Project (GTEx) v8 (25) and breast and prostate tumor tissue from The Cancer Genome Atlas (TCGA) (26). We included only individuals of European ancestry due to the small sample sizes available for other demographics ( $N=337$ for GTEx breast, $N=186$ for GTEx prostate, $N=437$ for TCGA breast, $N=349$ for TCGA prostate). For both GTEx and TCGA, we only consider SNPs and genes on autosomes, restricted to SNPs with minor allele frequency greater than or equal to $1 \%$, and excluded SNPs that deviated from Hardy-Weinberg equilibrium at $P<10^{-6}$. 
medRxiv preprint doi: https://doi.org/10.1101/2022.02.08.22270601; this version posted February 23, 2022. The copyright holder for this preprint (which was not certified by peer review) is the author/funder, who has granted medRxiv a license to display the preprint in perpetuity.

It is made available under a CC-BY 4.0 International license.

We used the BioConductor package biomaRt for ENSEMBL gene biotype annotations (29).

Using these annotations, we defined pcGenes as those labeled "protein-coding" and non-coding

RNAs (ncRNAs) as those labeled otherwise; we exclude transcripts labelled as "pseudogenes".

108 These annotations included 16,582 pcGenes and 5,650 ncRNAs in GTEx breast, 16,827

109 pcGenes and 5,862 ncRNAs in GTEx prostate, 21,648 pcGenes and 1,261 ncRNAs in TCGA

110 breast, and 15,773 pcGenes and 548 ncRNAs in TCGA prostate. We considered all provided

111 GTEx covariates: 5 genotype-based principal components (PCs), up to 60 probabilisticallyestimated expression residuals (PEER) factors, age, sex, and sequencing platform and protocol

113 (25). For TCGA, we calculated genotype PCs using PLINK v1.93 (30), calculated up to 50 hidden components of expression (HCP) using Rhcpp $(31,32)$, and included the following covariates: age, estrogen receptor subtype, menopausal status, and disease pathological stage. For prostate tumors, we include the following covariates: age, sequencing platform, and

117 protocol.

We integrated eQTL results with GWAS summary statistics for overall and subtype-specific breast and overall prostate cancer risk. We obtained European-ancestry specific overall and subtype-specific GWAS summary statistics for breast cancer risk from the BCAC Consortium (2). We studied 5 intrinsic breast cancer molecular subtypes, defined by combinations of estrogen (ER)-, progesterone (PR)-, and human epidermal growth factor receptor (HER2) and tumor grade (2): Luminal A-like (ER + and/or PR + , HER2-, grade 1 or 2); (2) luminal Blike/HER2-negative (ER + and/or PR + , HER2-, grade 3); (3) luminal B-like/HER2-positive (ER + and/or PR + , HER2 +); (4) HER2-positive/non-luminal (ER- and PR-, HER2+), and (5)

127 TNBC (ER-, PR-, HER2-). We obtained European-ancestry specific GWAS summary statistics 128 for prostate cancer risk from the PRACTICAL Consortium (1). 


\section{eQTL mapping}

We used a multiple linear regression model in MatrixEQTL to detect local- and distal-eQTLs (33). Here, we define a local-eQTL as a variant within $1 \mathrm{Mb}$ of the gene body and a distal-eQTL as a variant outside the $1 \mathrm{Mb}$ window. eQTLs outside this $1 \mathrm{Mb}$ window are unlikely to have direct effects on the promoters or enhancers of the gene and are more likely to have transacting mechanisms $(17,18)$.

To determine a set of covariates that maximizes the number of detected distal-eQTLs for pcGenes, we iterated on eQTL mapping using SNPs on Chromosome 22. For breast tumor tissue, we found that the optimized covariate set for local-eQTL mapping included all of the clinical covariates (age, estrogen receptor subtype, menopause status, and disease pathological stage), the first 3 PCs, and the first 8 HCPs. For prostate tumor tissue, we included age, sequencing platform, protocol as covariates and used 5 genotype PCs and 10 HCPs as the optimized set of covariates (31). For data from GTEx, we used the full set of provided covariates for non-cancerous breast and prostate tissue local- and distal-eQTL mapping. We then run genome-wide eQTL mapping with these optimized sets of covariates.

\section{Mediation analysis for distal-eQTL mapping}

148 We first identify a testing triplet, consisting of (1) a SNP $s,(2)$ a distal pcGene $G$ associated with 149 SNP $s$ with nominal $P<10^{-6}$, and (3) a set of local ncRNAs $m_{1}, \ldots, m_{M}$, all associated with SNP $150 s$ with nominal $P<10^{-6}$. As in previous distal-eQTL studies, we use a liberal P-value threshold

151 to increase the number of testing triplets subjected to rigorous permutation-based mediation analysis $(18,21,23)$. Next, we fit the following two sets of linear regressions for mediation analysis $(21,23)$ :

$$
Y_{G}=X_{s} \beta_{s}+M \beta_{M}+X_{C} \beta_{C}+\epsilon_{G}, \quad \epsilon_{G} \sim N\left(0, \sigma^{2} I_{n}\right)
$$


where $Y_{G}$ is a vector of expression for gene $G, X_{S}$ is a vector of dosages for SNP $s, \beta_{S}$ is the effect size of SNP $s$ on gene $G, M$ is the expression matrix of $m$ ncRNAs, $\beta_{M}$ is the effects of the $M$ ncRNAs on $Y_{G}, X_{C}$ is a matrix of covariates, and $\epsilon_{G}$ is a random error term. The $j$ th ncRNA is modeled as

$$
M_{j}=X_{S} \alpha_{M_{j}}+X_{C} \alpha_{C, j}+\epsilon_{M_{j}}, 1 \leq j \leq m, \quad \epsilon_{M_{j}} \sim N\left(0, \sigma_{M_{j}}^{2} I_{n}\right)
$$

where $M_{j}$ is the vector of expression for the $j$ th ncRNA, $\alpha_{M_{j}}$ is a vector of effects of SNP $s$ on and $\epsilon_{M_{j}}$ represents a random error term.

We define the total mediation effect (TME) as $T M E=\alpha_{M} \cdot \beta_{M}$ and the mediation proportion (MP) as $M P=\min \left(1, \frac{\alpha_{M} \cdot \beta_{M}}{\beta_{S}+\alpha_{M} \cdot \beta_{M}}\right)$. We test $H_{0}: T M E=0$ vs. $H_{1}: T M E \neq 0$ via permutation testing with 10,000 draws.

\section{Gene-based association testing (GBAT)}

169 We applied GBAT (24) with modifications to identfy ncRNAs with genetically-regulated expression (GReX) associated with distal pcGenes. First, we removed multi-mapped reads using previously provided annotations (34). Then, we estimated the heritability of ncRNA expression using GCTA v1.93 (35), excluding genes with limited evidence of heritability (P > within $1 \mathrm{Mb}$ using elastic net, LASSO (36) and SuSiE (37), excluding ncRNAs with crossvalidation $R^{2}<0.01$. We then employed MatrixEQTL to estimate the association between the ncRNA GReX and distal pcGene expression, adjusting for the optimized set of covariates from

177 eQTL mapping (33). Lastly, to identify a set of SNPs that best explains distal ncRNA-pcGene association, we used SuSiE fine-mapping with default parameters to define a $90 \%$ credible set 


\section{Colocalization with cancer risk}

182 To identify any potentially overlapping signals between local-eQTLs of ncRNAs, ncRNA-

183 mediated distal-eQTLs of pcGenes, and cancer risk, we employed the Bayesian colocalization

184 method, coloc (27). coloc estimates the posterior probability that the same SNP explains both

185 the eQTL and the GWAS signal at a given locus. We used standard parameters with default

186 priors $\left(p_{1}=10^{-4}, p_{2}=10^{-4}\right.$, and $\left.p_{12}=10^{-6}\right)$ to estimate the colocalization posterior probability. We

187 considered an eQTL signal to colocalize with a GWAS signal if the posterior probability of colocalization through one SNP (PP.H4 in Giambartolomei et al) was greater than 0.75 (27).

\section{Genetically-regulated expression analysis of ncRNAs}

191 We identified any cancer associations for the genetically-regulated expression (GReX) of any ncRNAs that showed significant mediation of multiple distal-eQTLs of distant pcGenes. First, association with the GReX of an ncRNA (28). We define transcriptome-wide significance as $\mathrm{P}<$ $2.5 \times 10^{-6}$ and permutation test $\mathrm{P}<0.05$.

\section{Data Availability}

201 GTEx v8 data were obtained through dbGAP Study Accession phs000424.v8.p2. TCGA

202 genotype were obtained through dbGAP Study Accession phs000178.v11.p8 and expression

203 and covariate data was obtained from the Broad GDAC Firehose repository

204 (https://gdac.broadinstitute.org). Prostate cancer GWAS summary statistics were obtained from

205 the Prostate Cancer Association Group to Investigate Cancer Associated Alterations in the 
medRxiv preprint doi: https://doi.org/10.1101/2022.02.08.22270601; this version posted February 23, 2022. The copyright holder for this preprint (which was not certified by peer review) is the author/funder, who has granted medRxiv a license to display the preprint in perpetuity.

It is made available under a CC-BY 4.0 International license .

Genome (PRACTICAL) Consortium: http://practical.icr.ac.uk/blog/wp-

content/uploads/uploadedfiles/oncoarray/MetaSummaryData/meta v3 onco euro overall Chr

208 All 1 release.zip. Breast cancer GWAS summary statistics were obtained from the Breast

209 Cancer Association Consortium (BCAC):

210 https://bcac.ccge.medschl.cam.ac.uk/bcacdata/oncoarray/oncoarray-and-combined-summary-

result/gwas-summary-associations-breast-cancer-risk-2020/. Sample code for this analysis is

212 available at https://github.com/ColetheStatistician/ncRNAlnBreastCancer/.

\section{RESULTS}

215 In this work, we uncover hidden mechanisms contributing to genetic risk for breast and prostate cancer mediated by ncRNAs, systematically exploring one regulatory hypothesis: distal mediation of pcGene expression regulation in non-cancerous and tumor breast and prostate tissue (Figure 1). Specifically, we identify distal-eQTLs of protein-coding genes (pcGenes) that are significantly mediated by ncRNAs local to these distal-eQTLs and assess if they overlap with genetic signal for cancer risk.

\section{Multiple ncRNAs mediate distal-eQTLs in breast and prostate tissue}

Distal-eQTL mapping through mediation analysis

We conducted distal-eQTL mapping through ncRNA mediation in GTEx (25) and TCGA (26).

The number of distal-eQTLs of pcGenes that are significantly mediated by ncRNAs are reported

in Table 1 and Supplemental Table S1-2. Distributions of TME and MP in tumor tissue showed

227 a larger range than in non-cancerous tissue for both breast and prostate, and median TME and 228 MP were higher in tumor tissue (Supplemental Figure S2).

230 In non-cancerous breast tissue, pcGenes with cross-chromosomal distal-eQTLs with large ncRNA-mediated effects included PUM1 and PCBP1 (Figure 2A), both of which influence 
medRxiv preprint doi: https://doi.org/10.1101/2022.02.08.22270601; this version posted February 23, 2022. The copyright holder for this preprint (which was not certified by peer review) is the author/funder, who has granted medRxiv a license to display the preprint in perpetuity.

It is made available under a CC-BY 4.0 International license .

232

233

234

235

236

237

238

239

240

241

242

243

244

245

246

247

248

249

250

251

252

253

254

255

256

257

tumorigenesis (39-41). In breast tumors, we found MT4 and GPRC6A have large mediated distal effects. MT4 belongs to the metallothionein family involved in breast cancer carcinogenesis $(42,43)$, and $G P R C 6 A$ is a part of the androgen receptor signaling pathway $(44,45)$. In non-cancerous prostate tissue, we detected large distal mediation effects for genes such as $R A F 1$, a proto-oncogene (46) and $L G R 5$, a gene associated with prostatic regeneration and overexpressed in prostate tumors (47). We also detected a number of olfactory receptors (OR2T1, OR10G8, OR10S1) with large mediated effects in prostate tumor. Olfactory receptors are associated with prostate cancer progression but generally have low expression in prostate tumors $(48,49)$.

Owing mainly to a larger set of nominally-significant distal-eQTLs in tumor tissues and larger sample sizes in TCGA than GTEx, we found nearly four times as many significantly mediated distal-eQTLs in tumor tissue compared to non-cancerous tissue. Among distal-eQTLs detected in tumor samples, we observed that multiple ncRNAs mediated distal-eQTLs with many different pcGenes (vertical bands in Figure 2A). One such ncRNA in breast tumors is LINC00301, showing significant mediation of 1,103 distal-eQTLs across 53 unique SNPs and 53 unique pcGenes. Many of these pcGenes belong to the GAGE protein family, which promotes breast cancer cell invasion and has shown evidence of distal genetic regulation (50,51). LINC00301 itself has been implicated in facilitating tumor progression and immune suppression, albeit in lung cancer (52). Another example of such an ncRNA in breast tumors is miR-548f-4, a commonly mutated microRNA in multiple cancers (53), mediating more than 300 distal-eQTLs for 16 unique pcGenes, including GUCA2B, upregulated in breast cancer metastases (54), and CYP2C9, a target of tamoxifen (55). In contrast, only two ncRNAs in non-cancerous breast tissue showed significant mediation of more than 50 distal pcGenes. One of these genes, FAM106A, mediated distal-eQTLs of 13 pcGenes, including BTN3A2, a prognostic marker for breast cancer (56). In both non-cancerous and tumor breast tissue, three pcGenes (PRCC1, 
medRxiv preprint doi: https://doi.org/10.1101/2022.02.08.22270601; this version posted February 23, 2022. The copyright holder for this preprint (which was not certified by peer review) is the author/funder, who has granted medRxiv a license to display the preprint in perpetuity.

It is made available under a CC-BY 4.0 International license .

CYP2C9, and ATG14) showed significant mediation through ncRNAs, though the sets of pcGene targets across non-cancerous and tumor tissue are distinct.

In prostate tumors, LINC02903 showed significant mediation with the most distal-eQTLs (177 eQTLs across 8 pcGenes). These pcGenes include $F A B P 9$, an upregulated gene in prostate carcinomas with prognostic value (57), and $M T N R 1 B$, a gene harboring nominal risk variants for prostate cancer (58). Another ncRNA with significant TME for nearly 100 distal-eQTLs across 20 pcGenes was SDHAP2. Many of these pcGenes have been implicated in prostate cancer and metastasis pathways, including TMEM207, FADS6, MTNR1B, SLC26A8, and FGF23 (5961). Similar to breast tissue, only two ncRNAs showed significant mediation of more than 20 distal eQTLs in prostate tissue: FBXO30-DT and SNHG2, which has been implicated in tumorigenesis and proliferation in multiple cancers (62-64). A majority (22/26) of distal-eQTLs mediated by $F B X O 30-D T$ are for $\mathrm{OVCH}$, which has been implicated in prostate risk through GWAS $(65,66)$. The majority of distal-eQTLs mediated by SNHG2 are for RAF1, a therapeutic target for multiple cancers (46). We did not detect any shared ncRNAs or pcGenes across noncancerous and tumor prostate tissue.

\section{Gene-based distal-eQTL mapping}

Next, we conducted gene-level distal eQTL mapping using GBAT (24) to identify ncRNAs that are regulated by multiple weak local genetic effects and may have distal effects on pcGenes; these ncRNAs are likely to be missed by the mediation framework. Comparing to mediated pcGenes from mediation analysis (Table 1), we found a similar order of magnitude of pcGenes with distal associations with ncRNAs using GBAT (Table 2). We again detected far more distal ncRNA-pcGene directional associations in tumor compared to non-cancerous tissue (Table 2,

Supplemental Table S1-2). In addition, the distribution of ncRNA-pcGene effect sizes is shifted downwards in tumor tissue, compared to non-cancerous tissue, though the number of effect 
medRxiv preprint doi: https://doi.org/10.1101/2022.02.08.22270601; this version posted February 23, 2022. The copyright holder for this preprint (which was not certified by peer review) is the author/funder, who has granted medRxiv a license to display the preprint in perpetuity.

It is made available under a CC-BY 4.0 International license .

sizes in these distributions are far less for non-cancerous tissue distal associations

(Supplemental Figure S2). In breast tumors, we found large distal genetic associations with pcGenes like OXNAD1, an RNA-binding protein that is associated with pan-cancer survival rates and involved with tumor invasion and metastasis $(66,67)$, and $L C N 9$, part of the lipocalin family that promotes breast cancer metastasis (68). In prostate tumors, we detected multiple large distal genetic associations with genes in the pro-proliferative keratin-associated protein family (KRTAP13-3, KRTAP13-4, KRTAP10-8) (69) (Figure 2).

Though distal genetic effects of ncRNAs in non-cancerous breast or prostate tissue were sparse, we found three ncRNAs with genetic associations with pcGenes across both breast and prostate tissue: LINC01678, FAM106A, and AP001056.1. These ncRNAs also target the same pcGenes (LOC102724159, CCDC144A, GATD3B, and a paralog to TRAPPC10), all with no catalogued functions in cancer.

Again, in tumor-specific gene-gene associations, many ncRNAs had associations with multiple pcGenes, leading to vertical bands in the location plots in Figure 2B. For example, in breast tumors, LINC000906, a predicted miRNA sponge in breast tumors (70), was associated with 115 pcGenes. The largest association was with MS4A5, whose hypomethylation is shown to be prognostic for multiple cancer types $(71,72)$. Another ncRNA associated with multiple different pcGenes is LINC00115, a known promoter of breast cancer metastasis and progression (7375). Many of these targets are related to interferons (IFNA17 and IFNW1), immune system cytotoxicity ( $R A C 2$ and $D D B 2)$, or secretory proteins ( $P R H 1$ and $P R H 2)$.

In prostate tumors, FAM138F showed distal genetic associations with 57 distinct pcGenes, many of which are involved in amino acid activation in prostate cancer ( HDAC2, NT5DC1, NUS1, and PREP) and protein stability (PDCD2, TCP1). Additionally TDRG1, shown to be 
medRxiv preprint doi: https://doi.org/10.1101/2022.02.08.22270601; this version posted February 23, 2022. The copyright holder for this preprint (which was not certified by peer review) is the author/funder, who has granted medRxiv a license to display the preprint in perpetuity.

It is made available under a CC-BY 4.0 International license .

associated with progression and metastases in multiple cancers $(76,77)$, showed multiple distal genetic associations with pcGenes, including the cancer-initiating pluripotency factor PRDM14 (78) and multiple genes related to olfactory stimulus (OR1OH3, OR2T1, OR51V1, and UGT2A1) (49). Taken together, these distal eQTL mappings suggest the ncRNAs have strong influences on gene expression of multiple pcGenes in both non-cancerous and tumor tissue.

\section{Overlap of miRNA-pcGene pairs with target prediction databases}

For in-silico validation, we queried TargetScan $(79,80)$, a database that curates computationally predicted RNA targets of miRNAs, for any miRNAs that our analysis detected to mediate distaleQTLs of pcGenes. Out of 522 pairs of miRNAs and pcGenes across 72 unique miRNAs identified through our analysis, we found that 184 pairs were included in the TargetScan database (Supplemental Table S3). miRNA-pcGene pairs identified in our eQTL analysis are found in TargetScan at an enrichment ratio of $8.2(95 \% \mathrm{Cl}$ : $[6.68,10.09])$, compared to the universe of all miRNA-target pairs in TargetScan (approximately 3.56 million) and roughly 159,000 miRNA-target pairs in TargetScan for the 72 miRNA families identified. A majority of these miRNAs ( $82 \%$ of miRNAs detected in eQTLs) are conserved only across humans and mice but well-annotated. Though this intersection with TargetScan does not implicate the miRNA in distal regulation of the proposed pcGene, it provides some computational validation of this relationship using different methodology (sequence similarity vs. eQTL mapping).

\section{Distal-eGenes are enriched for tumorigenesis and cancer progression gene pathways}

To assess enriched biological processes or pathways by sets of prioritized pcGenes (called distal-eGenes), we conducted gene ontology enrichments (81). Overall, compared to all expressed pcGenes in the transcriptome, distal-eGenes in non-cancerous tissue (combining breast and prostate) were significantly enriched (FDR-adjusted $P<0.05$ ) for many relevant ontologies: immune processes, genes targeted by epigenetic regulation, microRNA targets in 
medRxiv preprint doi: https://doi.org/10.1101/2022.02.08.22270601; this version posted February 23, 2022. The copyright holder for this preprint (which was not certified by peer review) is the author/funder, who has granted medRxiv a license to display the preprint in perpetuity.

It is made available under a CC-BY 4.0 International license .

cancer, and oxidoreductase activity. In comparison, distal-eGenes detected in tumor tissue showed enrichments mainly for chemical and sensory receptors and intermediate filament cytoskeleton (Supplemental Figure S3-4). Comparing tissue-prioritized distal-eGenes (breastspecific or prostate-specific pcGenes to the protein-coding transcriptome), we found distaleGenes enrichments detected in prostate tissue for immune pathway ontologies, including the multiple activations of immune cells, and known tumorigenic pathways, like the JAK-STAT cascade and PI3K-Akt signaling $(82,83)$. We did not detect any significant enrichments for the breast-specific distal-eGenes (Supplemental Figure S5).

We also conducted comparisons of distal-eGenes between non-cancerous and tumor state in both breast and prostate tissue (Figure 3). We find that, compared to distal-eGenes prioritized in breast tumors, non-cancerous breast distal-eGenes were enriched for cytokine and leukocyte production, response, and function, as well as membrane transport and binding. We observed similar enrichments when we compared non-cancerous prostate distal-eGenes to those from prostate tumors, with additional cell death and morphogenesis ontologies enrichments. In contrast, across both breast and prostate tissue, tumor-specific distal-eGenes, compared to non-cancerous distal-eGenes, mainly showed enrichments for olfactory and chemical stimulus response, intermediate filament cytoskeleton localization, and epidermis development. These ontologies are consistent with cancer progression, as olfactory receptors have been validated as prognostic biomarkers in prostate cancers and are overexpressed in more aggressive breast tumors $(48,49,84,85)$, more aggressive breast cancers are enriched for genes that influence epidermal growth (86) and cytoskeletal dysregulation is key to cancer cell invasion, progression, and metastasis (87-89).

\section{Distal-eQTLs overlap with genetic signal for breast and prostate cancer risk}


medRxiv preprint doi: https://doi.org/10.1101/2022.02.08.22270601; this version posted February 23, 2022. The copyright holder for this preprint (which was not certified by peer review) is the author/funder, who has granted medRxiv a license to display the preprint in perpetuity.

It is made available under a CC-BY 4.0 International license .

Lastly, we integrated these eQTL results with GWAS summary statistics for overall prostate and overall and molecular subtype-specific breast cancer risk (1,2). A total of 84 detected ncRNAs are within $0.5 \mathrm{Mb}$ of a GWAS SNP at $\mathrm{P}<5 \times 10^{-8}$, the majority for overall prostate and breast cancer risk, which have the largest GWAS sample sizes (Figure 4A, Supplemental Table S12). Among pairs of ncRNAs and pcGenes where the ncRNA is $0.5 \mathrm{Mb}$ from a GWAS SNP for either breast or prostate cancer risk, we identified 30 pairs (15 for overall breast cancer and 10 for LumA breast cancer, five for prostate cancer) where at least one of the ncRNA local-eQTL or pcGene distal-eQTL colocalized with the GWAS signal at the locus with PP.H4 $\geq 0.75$

(Supplemental Figure S6, Supplemental Table S4). In total, we detected 10 independent overall or LumA-specific breast cancer risk GWAS signals and one independent prostate cancer risk GWAS signal may be, in part, explained by distal genetics effects on pcGenes mediated by local-ncRNAs.

We found that distal-eQTLs of CSH1 mediated by RFPL1S strongly colocalize with GWAS signal for prostate cancer risk. (PP.H4 = 0.913) (Figure 4B). CSH1 codes for a somatotropin hormone with paracrine signaling functions promoting cell division and growth in glands (90). Using non-cancerous breast tissue eQTLs, we found strong colocalization with overall breast cancer risk with local-eQTLs of RUSC1-AS1 and distal-eQTLs of SH2B1 (Figure 4C). Two different SNPs carried the largest posterior probability of colocalization for the local(rs2297480) and distal-eQTLs (rs2075571), which are in moderate, yet statistically significant, linkage disequilibrium $\left(D^{\prime}=0.51, R^{2}=0.131, P<0.001\right)$. RUSC1-AS1 has shown evidenced silencing of genes through epigenetic signaling and is correlated with breast cancer progression $(91,92)$. Additionally, $S H 2 B 1$ is involved with cytokine signaling in cell proliferation and migration (93). We also found strong colocalization with LumA-specific breast cancer risk with localeQTLs of THBS3-AS1 and distal-eQTLs of SLC39A13 in non-cancerous breast tissue. The same SNP showed the maximum posterior probability for colocalization with both the local- and 
medRxiv preprint doi: https://doi.org/10.1101/2022.02.08.22270601; this version posted February 23, 2022. The copyright holder for this preprint (which was not certified by peer review) is the author/funder, who has granted medRxiv a license to display the preprint in perpetuity.

It is made available under a CC-BY 4.0 International license .

distal-eQTL signal. Though the ncRNA has not been implicated in cancer risk or progression, SLC39A13 facilitates metastasis in ovarian cancer by activating the Src/FAK signaling pathway (94).

For overall breast cancer risk, we also detect strong colocalization between eQTLs and GWAS signals at the $17 \mathrm{q} 21.31$ locus. This locus houses a large, common inversion polymorphism associated with breast and ovarian cancer prognosis (95-97), as well as widespread associations with multiple phenotypes (98-101). In particular, we found that the ncRNA KANSL1-AS1 potentially mediates distal-eQTLs of multiple pcGenes. All but one of these pcGenes are on Chromosome 17, near the end of the 17q21.31 region; the last pcGene we detected is TXNRD3 at 3q21.3. We were interested in disentangling effects of the $\mathrm{H} 2$ inversion on gene expression and breast cancer risk, with the proposed causal diagram presented in Figure 5A. First, we estimated haplotypes of the H2 inversion in GTEx (102). We found that KANSL1-AS1 and the associated pcGenes near 17q21.31 all have significant associations with the H2 inversion (Figure 5B). Next, we reran mediation analysis for SNPs local to KANSL-AS1 and these detected pcGenes. After accounting for $\mathrm{H} 2$, the distal mediation signal of KANSL-AS1 is attenuated for all pcGenes except $T X N R D 3$, suggesting that the inversion may be driving a significant portion of this signal. These analyses support our proposed causal model, that the genetics of the $\mathrm{H} 2$ inversion affect expression of the local ncRNA KANSL-AS1 and the distal pcGenes at the end of the inversion, which induces the eQTL associations (Figure 5A).

$\mathrm{H} 2$ inversion-adjusted colocalization analyses also support this model. A salient example is shown in Figure 5D, with Manhattan plots from colocalization analysis of overall breast cancer risk, local-eQTLs of KANSL-AS1, and distal-eQTLs of CRHR1. Colocalization analysis unadjusted for $\mathrm{H} 2$, showed nearly-perfect colocalization for both eQTL signals with GWAS (PP.H4 > 0.98 for both eQTLs), but after adjustments, the eQTL signals are completely 
medRxiv preprint doi: https://doi.org/10.1101/2022.02.08.22270601; this version posted February 23, 2022. The copyright holder for this preprint (which was not certified by peer review) is the author/funder, who has granted medRxiv a license to display the preprint in perpetuity.

It is made available under a CC-BY 4.0 International license .

removed. In fact, the standardized effect sizes for local-eQTLs of KANSL1-AS1 showed strong correlation with the standardized effect sizes for local-QTLs of the $\mathrm{H} 2$ inversion (Figure 5E), and the local-QTL signal for the H2 inversion strongly colocalized (PP.H4 $=0.99$ ) with the GWAS signal in the locus (Figure 5F). These results illustrate that the structural inversion in the locus likely accounts for both cis-genetic control of KANSL1-AS1 and the associated pcGenes further downstream on Chromosome 17. Furthermore, we emphasize further examination of the $\mathrm{H} 2$ inversion and other structural variants in the locus for its impact on local and distal gene expression, as well as cancer susceptibility, especially to elucidate if SNPs with widespread local or distal associations with gene expression are affected by confounding due to structural variants or other aberrations.

We also studied the cancer risk associations of ncRNAs with predicted large transcriptomic effects using a genetically-regulated expression (GReX) approach (Methods). At $\mathrm{P}<2.5 \times 10^{-6}$ and permutation $\mathrm{P}<0.05$, we identify 33 ncRNA-level associations (Figure 6, Supplemental Table S5), predominantly for overall and subtype-specific breast cancer risk. Only one ncRNA, SDHAP2, showed an association with overall prostate cancer risk (Figure 6); as we restrict to ncRNAs mediating distal-eQTLs and not necessarily in known prostate cancer GWAS loci, we do not recover any ncRNAs detected by Guo et al's analysis of long-ncRNAs in prostate cancer (103). A couple ncRNAs prioritized in associations of breast cancer risk using ncRNA GReX in non-cancerous breast tissues have been previously noted. Common non-synonymous SNPs in HCG9 have previously been implicated in breast cancer GWAS (104). In addition, CEROX1, a cataloged post-transcriptional regulator of mitochondrial catalytic activity, has been implicated in distal alterations of metabolic pathways in breast cancers $(14,105)$. ncRNAs prioritized in breast tumor GReX-associations with breast cancer risk mainly included micro- and snoRNAs. Of these, miR-519d has been shown to suppress breast cancer cell growth by targeting distal 
medRxiv preprint doi: https://doi.org/10.1101/2022.02.08.22270601; this version posted February 23, 2022. The copyright holder for this preprint (which was not certified by peer review) is the author/funder, who has granted medRxiv a license to display the preprint in perpetuity.

It is made available under a CC-BY 4.0 International license .

molecular features(106,107). GReX associations prioritize these ncRNAs for further investigation of their functional effects in breast and prostate tissue.

\section{DISCUSSION}

In this work, we systematically identify distal-eQTLs of pcGenes that are mediated by ncRNAs in non-cancerous and tumor breast and prostate tissue. We then show that many of these ncRNA-mediated distal-eQTLs of pcGenes overlap with GWAS signals for breast and prostate cancer, both with known GWAS loci and novel genetic loci undetected by GWAS. Taken together, our results suggest that distal genetic effects on pcGenes mediated by ncRNAs may be a common mechanism underlying genetic signals and ncRNAs have a widespread role as distal transcriptional regulators in prostate and breast tissue. We observed more distal ncRNApcGene directional associations in tumor than non-cancerous tissue, suggesting that tumor tissues have multiple activated gene regulatory networks with potential effects on disease pathogenesis or progression. Our results implicating distal interactions between ncRNAs and pcGenes are attractive for further in silico and experimental study.

We find many colocalized eQTL signals for ncRNAs and pcGenes in the 17q21.31 region, many of which have been prioritized by previous genetic association studies. For example, a transcriptome-wide association study (TWAS) of estrogen receptor subtype-specific breast cancer, identified ncRNA KANSL-AS1 (108), which has also been associated with ovarian cancer (109). In our analysis, KANSL-AS1 mediated multiple breast cancer-associated pcGenes further downstream on Chromosome 17 and colocalized almost perfectly with the GWAS association, suggesting widespread distal effects of KANSL-AS1 (108,110-114). However, after accounting for the large and common $\mathrm{H} 2$ inversion in the 17q21.31 locus, the distal effects of KANSL1-AS1 were largely attenuated, pointing to correlated effects of large structural aberrations on gene expression and disease etiology in this region (115-118). These results 
medRxiv preprint doi: https://doi.org/10.1101/2022.02.08.22270601; this version posted February 23, 2022. The copyright holder for this preprint (which was not certified by peer review) is the author/funder, who has granted medRxiv a license to display the preprint in perpetuity.

It is made available under a CC-BY 4.0 International license .

also suggest that structural aberrations, like the 17q21.31 $\mathrm{H} 2$ inversion, have large effects on gene expression, not only locally, but also distally. Our results also serve as a cautionary tale: future gene expression analyses must delineate the eQTL signal in a locus from chromosomal aberrations, especially when integrating with GWAS signals. Comprehensive analyses of the transcriptomic effects of genomic aberrations in tumor tissue are needed.

We conclude with limitations of our study. First, we rely on Ensembl annotations of gene biotypes to define our sets of ncRNAs and pcGenes. These annotations may be incomplete, and accordingly, we may have ignored multiple non-coding transcripts (119). Next, as our localand distal-eQTL signals are the same cohor, we were unable to use multi-trait colocalization methods, like moloc or Primo (120,121). A more flexible framework that allows for shared molecular QTL signal could be developed to fully interrogate the mediated-distal QTL signal, in the context of complex trait etiology. Next, we do not account for copy number variation or structural variation to disentangle these potentially disparate signals. Future studies should consider corrections for inversions, translocations, or genomic imbalances. Lastly, due to limited sample sizes in TCGA, we could not assess the effects of molecular subtype heterogeneity on eQTL mapping in tumor tissue. Previously, subtype-specific genetic architecture of gene expression regulation has been suggested by previous studies $(5,122,123)$, with some distal genetic associations detected for genes that are highly predictive of molecular subtypes (124). Robust subtype-specific analyses in breast cancer can be informative for both subtype-specific risk and outcomes.

\section{Our study provides evidence supporting trans-acting regulation by ncRNAs as a potential} biological mechanism relevant to breast and prostate cancer etiology. Particularly, our results emphasize that larger samples of tissue- and tumor-specific transcriptomics datasets need to be 
collected to study often ignored transcripts and explore more complex regulatory hypotheses to interpret GWAS risk loci for cancer.

\section{REFERENCES}

1. Schumacher FR, Al Olama AA, Berndt SI, Benlloch S, Ahmed M, Saunders EJ, et al. susceptibility loci. Nature Genetics. Nature Publishing Group; 2018;50:928-36. association study identifies 32 novel breast cancer susceptibility loci from overall and subtype-specific analyses. Nature Genetics. Nat Genet; 2020;52:572-81. identifies 65 new breast cancer risk loci. Nature. Europe PMC Funders; 2017;551:92-4. transcriptome-wide association study identifies new prostate cancer risk regions. Nature Communications [Internet]. Nature Publishing Group; 2018;9. Available from: https://www.ncbi.nlm.nih.gov/pmc/articles/PMC6172280/

5. Li Q, Seo JH, Stranger B, McKenna A, Pe'Er I, Laframboise T, et al. A novel eQTL-based analysis reveals the biology of breast cancer risk loci. Cell. NIH Public Access; 2013;152:633-633.

6. Kopp F, Mendell JT. Functional classification and experimental dissection of long noncoding RNAs. Cell. NIH Public Access; 2018;172:393-393.

510 7. Abascal F, Acosta R, Addleman NJ, Adrian J, Afzal V, Aken B, et al. Expanded 511 encyclopaedias of DNA elements in the human and mouse genomes. Nature. Nature 512 Research; 2020;583:699-710. 
medRxiv preprint doi: https://doi.org/10.1101/2022.02.08.22270601; this version posted February 23, 2022. The copyright holder for this preprint

(which was not certified by peer review) is the author/funder, who has granted medRxiv a license to display the preprint in perpetuity.

It is made available under a CC-BY 4.0 International license .

8. Statello L, Guo CJ, Chen LL, Huarte M. Gene regulation by long non-coding RNAs and its biological functions. Nature Reviews Molecular Cell Biology 2020 22:2. Nature Publishing Group; 2020;22:96-118.

9. Vance KW, Ponting CP. Transcriptional regulatory functions of nuclear long noncoding RNAs. Trends in Genetics. Elsevier; 2014;30:348-348.

10. Anastasiadou E, Jacob LS, Slack FJ. Non-coding RNA networks in cancer. Nature Reviews Cancer 2017 18:1. Nature Publishing Group; 2017;18:5-18.

11. Chen DL, Chen LZ, Lu YX, Zhang DS, Zeng ZL, Pan ZZ, et al. Long noncoding RNA XIST expedites metastasis and modulates epithelial-mesenchymal transition in colorectal cancer. Cell Death \& Disease 2017 8:8. Nature Publishing Group; 2017;8:e3011-e3011.

12. Slack FJ, Chinnaiyan AM. The Role of Non-coding RNAs in Oncology. Cell. Cell; 2019;179:1033-55.

13. Arun G, Diermeier SD, Spector DL. Therapeutic Targeting of Long Non-Coding RNAs in Cancer. Trends in molecular medicine. NIH Public Access; 2018;24:257-257.

14. Kamada S, Takeiwa T, Ikeda K, Horie-Inoue K, Inoue S. Long Non-coding RNAs Involved in Metabolic Alterations in Breast and Prostate Cancers. Frontiers in Oncology. Frontiers Media S.A.; 2020;10:2119-2119.

15. Peterson SM, Thompson JA, Ufkin ML, Sathyanarayana P, Liaw L, Congdon CB. Common features of microRNA target prediction tools. Frontiers in Genetics. Frontiers Research Foundation; 2014;5:23-23.

16. Porcu E, Sadler MC, Lepik K, Auwerx C, Wood AR, Weihs A, et al. Differentially expressed genes reflect disease-induced rather than disease-causing changes in the transcriptome. Nature Communications 2021 12:1. Nature Publishing Group; 2021;12:1-9.

17. Pierce BL, Tong L, Chen LS, Rahaman R, Argos M, Jasmine F, et al. Mediation Analysis Demonstrates That Trans-eQTLs Are Often Explained by Cis-Mediation: A Genome-Wide Analysis among 1,800 South Asians. PLoS Genetics. Public Library of Science; 2014;10. 
medRxiv preprint doi: https://doi.org/10.1101/2022.02.08.22270601; this version posted February 23, 2022. The copyright holder for this preprint

539 18. Pierce BL, Tong L, Argos M, Demanelis K, Jasmine F, Rakibuz-Zaman M, et al. Co-

540

541

542

543

544

545

546

547

548

549

550

551

552

553

554

555

556

557

558

559

560

561

562

563

564 occurring expression and methylation QTLs allow detection of common causal variants and shared biological mechanisms. Nature Communications. Nature Publishing Group;

2018;9:1-12.

19. Yang F, Gleason KJ, Wang J, Duan J, He X, Pierce BL, et al. CCmed: cross-condition mediation analysis for identifying replicable trans-associations mediated by cis-gene expression. Bioinformatics. Oxford Academic; 2021;37:2513-20.

20. Yang F, Wang J, Pierce BL, Chen LS. Identifying cis-mediators for trans-eQTLs across many human tissues using genomic mediation analysis. Genome Research. Cold Spring Harbor Laboratory Press; 2017;27:1859-71.

21. Bhattacharya A, Li Y, Love MI. MOSTWAS: Multi-Omic Strategies for Transcriptome-Wide Association Studies. Zhu X, editor. PLoS Genetics. 2021;17:e1009398-e1009398.

22. Bhattacharya A, Freedman AN, Avula V, Harris R, Liu W, Pan C, et al. Placental genomics mediates genetic associations with complex health traits and disease. Nat Commun. Nature Publishing Group; 2022;13:706.

23. Shan N, Wang Z, Hou L. Identification of trans-eQTLs using mediation analysis with multiple mediators. BMC Bioinformatics. BioMed Central Ltd.; 2019;20.

24. Liu X, Mefford JA, Dahl A, He Y, Subramaniam M, Battle A, et al. GBAT: a gene-based association test for robust detection of trans-gene regulation. Genome Biology. Genome Biology; 2020;21:211-211.

25. Aguet F, Barbeira AN, Bonazzola R, Brown A, Castel SE, Jo B, et al. The GTEx Consortium atlas of genetic regulatory effects across human tissues. Science. American Association for the Advancement of Science; 2020;369:1318-30.

26. Weinstein JN, Collisson EA, Mills GB, Shaw KRM, Ozenberger BA, Ellrott K, et al. The cancer genome atlas pan-cancer analysis project. Nature Genetics. Nature Publishing Group; 2013;45:1113-20. 
565 27. Giambartolomei C, Vukcevic D, Schadt EE, Franke L, Hingorani AD, Wallace C, et al. Bayesian Test for Colocalisation between Pairs of Genetic Association Studies Using Summary Statistics. Williams SM, editor. PLoS Genetics. Public Library of Science; 2014;10:e1004383-e1004383.

28. Gusev A, Ko A, Shi H, Bhatia G, Chung W, Penninx BWJH, et al. Integrative approaches

29. Durinck S, Spellman PT, Birney E, Huber W. Mapping identifiers for the integration of genomic datasets with the R/Bioconductor package biomaRt. Nature Protocols 2009 4:8. Nature Publishing Group; 2009;4:1184-91.

574 30. Purcell S, Neale B, Todd-Brown K, Thomas L, Ferreira MAR, Bender D, et al. PLINK: A Tool Set for Whole-Genome Association and Population-Based Linkage Analyses. Am J Hum Genet. 2007;81:559-75.

577 31. Mostafavi S, Battle A, Zhu X, Urban AE, Levinson D, Montgomery SB, et al. Normalizing RNA-Sequencing Data by Modeling Hidden Covariates with Prior Knowledge. PLoS ONE. Public Library of Science; 2013;8:e68141-e68141.

32. van Iterson M. mvaniterson/Rhcpp: A fast R implementation using Rcpp based on the original matlab HCP method for Normalizing RNA-Sequencing Data by Modeling Hidden Covariates with Prior Knowledge [Internet]. 2020. Available from: https://github.com/mvaniterson/Rhcpp

584 33. Shabalin AA. Gene expression Matrix eQTL: ultra fast eQTL analysis via large matrix operations. Bioinformatics (Oxford, England). Oxford University Press; 2012;28:1353-8.

586 34. Saha A, Battle A. False positives in trans-eQTL and co-expression analyses arising from 587 RNA-sequencing alignment errors [version 2; peer review: 3 approved]. F1000Research. $588 \quad$ F1000 Research Ltd; 2019;7:1860-1860.

589 35. Yang J, Lee SH, Goddard ME, Visscher PM. GCTA: a tool for genome-wide complex trait analysis. American journal of human genetics. Elsevier; 2011;88:76-82. 
medRxiv preprint doi: https://doi.org/10.1101/2022.02.08.22270601; this version posted February 23, 2022. The copyright holder for this preprint

591

592

593

594

595

596

597

598

599

600

601

602

603

604

605

606

607

608

609

610

611

612

613

614

615

36. Friedman J, Hastie T, Tibshirani R. Regularization Paths for Generalized Linear Models via Coordinate Descent. Journal of Statistical Software. 2010;33:1-22.

37. Wang G, Sarkar A, Carbonetto P, Stephens M. A simple new approach to variable selection in regression, with application to genetic fine mapping. Journal of the Royal Statistical Society: Series B. Blackwell Publishing Ltd; 2020;82:1273-300.

38. Endelman JB. Ridge Regression and Other Kernels for Genomic Selection with R Package rrBLUP. The Plant Genome. 2011;4:250-5.

39. Carrasco AM, Acosta O, Ponce J, Cotrina J, Aguilar A, Araujo J, et al. PUM1 and RNase P genes as potential cell-free DNA markers in breast cancer. Journal of Clinical Laboratory Analysis. John Wiley \& Sons, Ltd; 2021;35:e23720-e23720.

40. Shi P, Zhang J, Li X, Li W, Li H, Fu P. Long non-coding RNA NORAD inhibition upregulates microRNA-323a-3p to suppress tumorigenesis and development of breast cancer through the PUM1/elF2 axis. https://doi.org/101080/1538410120211934627. Taylor \& Francis; $2021 ; 20: 1295-307$.

41. Shi H, Li H, Yuan R, Guan W, Zhang X, Zhang S, et al. PCBP1 depletion promotes tumorigenesis through attenuation of p27Kip1 mRNA stability and translation. Journal of Experimental \& Clinical Cancer Research 2018 37:1. BioMed Central; 2018;37:1-18.

42. Goulding H, Jasani B, Pereira H, Reid A, Galea M, Bell J, et al. Metallothionein expression in human breast cancer. British Journal of Cancer 1995 72:4. Nature Publishing Group; 1995;72:968-72.

43. Si M, Lang J. The roles of metallothioneins in carcinogenesis. Journal of Hematology \& Oncology 2018 11:1. BioMed Central; 2018;11:1-20.

44. Michmerhuizen AR, Spratt DE, Pierce LJ, Speers CW. ARe we there yet? Understanding androgen receptor signaling in breast cancer. npj Breast Cancer 2020 6:1. Nature Publishing Group; 2020;6:1-19. 
616 45. Masi M, Garattini E, Bolis M, Di Marino D, Maraccani L, Morelli E, et al. OXER1 and RACK1-associated pathway: a promising drug target for breast cancer progression. Oncogenesis 2020 9:12. Nature Publishing Group; 2020;9:1-15.

619 46. Zhang L, Pattanayak A, Li W, Ko H-K, Fowler G, Gordon R, et al. A Multifunctional Therapy Approach for Cancer: Targeting Raf1 - Mediated Inhibition of Cell Motility, Growth, and Interaction with the Microenvironment. Molecular Cancer Therapeutics. American Association for Cancer Research; 2020;19:39-51.

47. Wang B, Wang X, Long JE, Eastham-Anderson J, Firestein R, Junttila MR. CastrationResistant Lgr5+ Cells Are Long-Lived Stem Cells Required for Prostatic Regeneration. Stem Cell Reports. Elsevier; 2015;4:768-768. Testosterone Metabolite 19-Hydroxyandrostenedione Induces Neuroendocrine TransDifferentiation of Prostate Cancer Cells via an Ectopic Olfactory Receptor. Frontiers in Oncology. Frontiers; 2018;0:162-162.

49. Neuhaus EM, Zhang W, Gelis L, Deng Y, Noldus J, Hatt H. Activation of an Olfactory Receptor Inhibits Proliferation of Prostate Cancer Cells. The Journal of Biological Chemistry. American Society for Biochemistry and Molecular Biology; 2009;284:1621816218.

50. Maine EA, Westcott JM, Prechtl AM, Dang TT, Whitehurst AW, Pearson GW. The cancertestis antigens SPANX-A/C/D and CTAG2 promote breast cancer invasion. Oncotarget.

637 51. Quiroz-Zárate A, Harshfield BJ, Hu R, Knoblauch N, Beck AH, Hankinson SE, et al. 638 Expression Quantitative Trait loci (QTL) in tumor adjacent normal breast tissue and breast tumor tissue. Wong K-K, editor. PLOS ONE. Public Library of Science; 2017;12:e0170181e0170181. 
641 52. Sun C-C, Zhu W, Li S-J, Hu W, Zhang J, Zhuo Y, et al. FOXC1-mediated LINC00301 facilitates tumor progression and triggers an immune-suppressing microenvironment in non-small cell lung cancer by regulating the HIF1a pathway. Genome Medicine 2020 12:1. BioMed Central; 2020;12:1-27.

645 53. Tuna M, Machado AS, Calin GA. Genetic and epigenetic alterations of microRNAs and 646 implications for human cancers and other diseases. Genes Chromosomes and Cancer.

647 Blackwell Publishing Inc.; 2016;55:193-214.

648 54. Xiao L, Zhou J, Liu H, Zhou Y, Chen W, Cui W, et al. RNA Sequence Profiling Reveals 649 Unique Immune and Metabolic Features of Breast Cancer Brain Metastases. Frontiers in $650 \quad$ Oncology. Frontiers; 2021;0:3213-3213.

651 55. MC B, U Y, MO B, O S, A B. Tamoxifen inhibits cytochrome P450 2C9 activity in breast cancer patients. Journal of chemotherapy (Florence, Italy). J Chemother; 2006;18:421-4.

56. Cai P, Lu Z, Wu J, Qin X, Wang Z, Zhang Z, et al. BTN3A2 serves as a prognostic marker and favors immune infiltration in triple-negative breast cancer. Journal of Cellular Biochemistry. John Wiley \& Sons, Ltd; 2020;121:2643-54.

57. MS AF, X G, SS F, W A-J, Z B, PR R, et al. The increased expression of fatty acid-binding protein 9 in prostate cancer and its prognostic significance. Oncotarget. Oncotarget; $2016 ; 7: 82783-97$.

58. MJ M, S L, NE A, CA H, D A, A B, et al. Association of type 2 diabetes susceptibility variants with advanced prostate cancer risk in the Breast and Prostate Cancer Cohort Consortium. American journal of epidemiology. Am J Epidemiol; 2012;176:1121-9.

662 59. Marín-Aguilera M, Reig Ò, Lozano JJ, Jiménez N, García-Recio S, Erill N, et al. Molecular profiling of peripheral blood is associated with circulating tumor cells content and poor survival in metastatic castration-resistant prostate cancer. Oncotarget. Impact Journals, LLC; 2015;6:10604-10604. 
medRxiv preprint doi: https://doi.org/10.1101/2022.02.08.22270601; this version posted February 23, 2022. The copyright holder for this preprint (which was not certified by peer review) is the author/funder, who has granted medRxiv a license to display the preprint in perpetuity.

It is made available under a CC-BY 4.0 International license .

666 60. Saigo C, Kito Y, Takeuchi T. Cancerous Protein Network That Inhibits the Tumor Suppressor Function of WW Domain-Containing Oxidoreductase (WWOX) by Aberrantly Expressed Molecules. Frontiers in Oncology. Frontiers; 2018;0:350-350.

669 61. S F, J W, Y Z, CJ C, M I. FGF23 promotes prostate cancer progression. Oncotarget. $670 \quad$ Oncotarget; 2015;6:17291-301.

671 62. Li Y-L, Tian H, Jiang J, Zhang Y, Qi X-W. Multifaceted regulation and functions of fatty acid desaturase 2 in human cancers. American Journal of Cancer Research. e-Century Publishing Corporation; 2020;10:4098-4098.

674 63. Chi J-R, Yu Z-H, Liu B-W, Zhang D, Ge J, Yu Y, et al. SNHG5 Promotes Breast Cancer 675 Proliferation by Sponging the miR-154-5p/PCNA Axis. Molecular Therapy - Nucleic Acids. $676 \quad$ Elsevier; 2019;17:138-49.

677 64. Damas ND, Marcatti M, Côme C, Christensen LL, Nielsen MM, Baumgartner R, et al. SNHG5 promotes colorectal cancer cell survival by counteracting STAU1-mediated mRNA destabilization. Nature Communications 2016 7:1. Nature Publishing Group; 2016;7:1-14.

680 65. Wang M, Takahashi A, Liu F, Ye D, Ding Q, Qin C, et al. Large-scale association analysis in Asians identifies new susceptibility loci for prostate cancer. Nature Communications 2015 6:1. Nature Publishing Group; 2015;6:1-7.

683 66. Sinnott-Armstrong N, Seoane JA, Sallari R, Pritchard JK, Curtis C, Snyder MP. Convergent 684 mutations in tissue-specific regulatory regions reveal novel cancer drivers. bioRxiv. Cold Spring Harbor Laboratory; 2020;2020.08.21.239954-2020.08.21.239954.

686 67. Kang D, Lee Y, Lee J-S. RNA-Binding Proteins in Cancer: Functional and Therapeutic Perspectives. Cancers. Multidisciplinary Digital Publishing Institute (MDPI); 2020;12:1-33.

688 68. Hu C, Yang K, Li M, Huang W, Zhang F, Wang H. Lipocalin 2: a potential therapeutic target for breast cancer metastasis. OncoTargets and therapy. Dove Press; 2018;11:8099-8099. 
690 69. Sack LM, Davoli T, Li MZ, Li Y, Xu Q, Naxerova K, et al. Profound Tissue Specificity in Proliferation Control Underlies Cancer Drivers and Aneuploidy Patterns. Cell. NIH Public Access; 2018;173:499-499.

693 70. Zhang J, Xu T, Liu L, Zhang W, Zhao C, Li S, et al. LMSM: A modular approach for identifying IncRNA related miRNA sponge modules in breast cancer. PLOS Computational Biology. Public Library of Science; 2020;16:e1007851.

71. Smith JC, Sheltzer JM. Genome-wide identification and analysis of prognostic features in human cancers. bioRxiv. Cold Spring Harbor Laboratory; 2021 ;2021.06.01.4462432021.06.01.446243.

699 72. Sun L, Zhang Y, Zhang C. Distinct Expression and Prognostic Value of MS4A in Gastric Cancer. Open Medicine. De Gruyter; 2018;13:178-178.

701

702

703

704

705

706

707

708

709

710

73. Hou R, Jiang L. LINC00115 promotes stemness and inhibits apoptosis of ovarian cancer stem cells by upregulating SOX9 and inhibiting the Wnt/ 3 -catenin pathway through competitively binding to microRNA-30a. Cancer Cell International $202121: 1$. BioMed Central; $2021 ; 21: 1-15$.

74. Li Q, Wang X, Zhou L, Jiang M, Zhong G, Xu S, et al. A Positive Feedback Loop of Long Noncoding RNA LINC00152 and KLF5 Facilitates Breast Cancer Growth. Frontiers in Oncology. Frontiers; $2021 ; 0: 899-899$.

75. Yuan C, Luo X, Duan S, Guo L. Long noncoding RNA LINC00115 promotes breast cancer metastasis by inhibiting miR-7. FEBS Open Bio. John Wiley \& Sons, Ltd; 2020;10:1230-7.

76. Ma Y, Xu XL, Huang HG, Li YF, Li ZG. LncRNA TDRG1 promotes the aggressiveness of gastric carcinoma through regulating miR-873-5p/HDGF axis. Biomedicine \& Pharmacotherapy. Elsevier Masson; 2020;121:109425-109425.

77. Hu X, Mu Y, Wang J, Zhao Y. LncRNA TDRG1 promotes the metastasis of NSCLC cell through regulating miR-873-5p/ZEB1 axis. Journal of Cellular Biochemistry. John Wiley \& Sons, Ltd; 2021;122:969-82. 
medRxiv preprint doi: https://doi.org/10.1101/2022.02.08.22270601; this version posted February 23, 2022. The copyright holder for this preprint (which was not certified by peer review) is the author/funder, who has granted medRxiv a license to display the preprint in perpetuity.

It is made available under a CC-BY 4.0 International license .

716 78. Tracey LJ, Justice MJ. Off to a bad start: Cancer initiation by pluripotency regulator PRDM14. Trends in genetics : TIG. NIH Public Access; 2019;35:489-489.

718 79. Agarwal V, Bell GW, Nam J-W, Bartel DP. Predicting effective microRNA target sites in mammalian mRNAs. Izaurralde E, editor. eLife. eLife Sciences Publications, Ltd;

80. McGeary SE, Lin KS, Shi CY, Pham TM, Bisaria N, Kelley GM, et al. The biochemical basis of microRNA targeting efficacy. Science. 2019;366:eaav1741.

81. Liao Y, Wang J, Jaehnig EJ, Shi Z, Zhang B. WebGestalt 2019: gene set analysis toolkit with revamped Uls and APIs. Nucleic Acids Research. 2019;47:199-205.

82. Thomas SJ, Snowden JA, Zeidler MP, Danson SJ. The role of JAK/STAT signalling in the pathogenesis, prognosis and treatment of solid tumours. British Journal of Cancer 2015 113:3. Nature Publishing Group; 2015;113:365-71.

83. Hoxhaj G, Manning BD. The PI3K-AKT network at the interface of oncogenic signalling and cancer metabolism. Nature Reviews Cancer 2019 20:2. Nature Publishing Group; 2019;20:74-88.

84. Masjedi S, Zwiebel LJ, Giorgio TD. Olfactory receptor gene abundance in invasive breast carcinoma. Scientific Reports 2019 9:1. Nature Publishing Group; 2019;9:1-12.

85. Kalra S, Mittal A, Gupta K, Singhal V, Gupta A, Mishra T, et al. Analysis of single-cell transcriptomes links enrichment of olfactory receptors with cancer cell differentiation status and prognosis. Communications Biology 2020 3:1. Nature Publishing Group; 2020;3:1-10.

86. Feng Y, Spezia M, Huang S, Yuan C, Zeng Z, Zhang L, et al. Breast cancer development and progression: Risk factors, cancer stem cells, signaling pathways, genomics, and molecular pathogenesis. Genes \& Diseases. Chongqing Medical University; 2018;5:77-77.

739 87. Holle AW, Kalafat M, Ramos AS, Seufferlein T, Kemkemer R, Spatz JP. Intermediate filament reorganization dynamically influences cancer cell alignment and migration. Scientific Reports 2017 7:1. Nature Publishing Group; 2017;7:1-14. 
742 88. Ong MS, Deng S, Halim CE, Cai W, Tan TZ, Huang RYJ, et al. Cytoskeletal Proteins in Cancer and Intracellular Stress: A Therapeutic Perspective. Cancers [Internet]. Multidisciplinary Digital Publishing Institute (MDPI); 2020;12. Available from: /pmc/articles/PMC7017214/

89. Tang $\mathrm{Y}, \mathrm{He} \mathrm{Y}$, Zhang $\mathrm{P}$, Wang J, Fan $\mathrm{C}$, Yang L, et al. LncRNAs regulate the cytoskeleton and related Rho/ROCK signaling in cancer metastasis. Molecular Cancer 2018 17:1. BioMed Central; 2018;17:1-10.

90. Strous GJ, Almeida ADS, Putters J, Schantl J, Sedek M, Slotman JA, et al. Growth Hormone Receptor Regulation in Cancer and Chronic Diseases. Frontiers in Endocrinology. Frontiers Media S.A.; 2020;11:867-867.

91. Hu CC, Liang YW, Hu JL, Liu LF, Liang JW, Wang R. LncRNA RUSC1-AS1 promotes the proliferation of breast cancer cells by epigenetic silence of KLF2 and CDKN1A. European review for medical and pharmacological sciences. Eur Rev Med Pharmacol Sci; 2019;23:6602-11.

92. Zhu L, Cui K, Weng L, Yu P, Du Y, Zhang T, et al. A panel of 8-IncRNA predicts prognosis of breast cancer patients and migration of breast cancer cells. PLOS ONE. Public Library of Science; 2021;16:e0249174-e0249174.

93. Yousaf N, Deng Y, Kang Y, Riedel H. Four PSM/SH2-B Alternative Splice Variants and Their Differential Roles in Mitogenesis *. Journal of Biological Chemistry. Elsevier; $2001 ; 276: 40940-8$.

94. Cheng X, Wang J, Liu C, Jiang T, Yang N, Liu D, et al. Zinc transporter SLC39A13/ZIP13 facilitates the metastasis of human ovarian cancer cells via activating Src/FAK signaling pathway. Journal of Experimental and Clinical Cancer Research. BioMed Central Ltd; $2021 ; 40: 1-15$ 
medRxiv preprint doi: https://doi.org/10.1101/2022.02.08.22270601; this version posted February 23, 2022. The copyright holder for this preprint

766

95. Permuth-Wey J, Lawrenson K, Shen HC, Velkova A, Tyrer JP, Chen Z, et al. Identification and molecular characterization of a new ovarian cancer susceptibility locus at 17q21.31. Nature communications. NIH Public Access; 2013;4:1627-1627.

96. Ruiz-Arenas C, Cáceres A, Moreno V, González JR. Common polymorphic inversions at 17q21.31 and 8p23.1 associate with cancer prognosis. Human Genomics. BioMed Central Ltd.; 2019;13:1-9.

97. Orsetti B, Courjal F, Cuny M, Rodriguez C, Theillet C. 17q21-q25 aberrations in breast cancer: combined allelotyping and CGH analysis reveals 5 regions of allelic imbalance among which two correspond to DNA amplification. Oncogene 1999 18:46. Nature Publishing Group; 1999;18:6262-70.

98. O'Brien HE, Hannon E, Hill MJ, Toste CC, Robertson MJ, Morgan JE, et al. Expression quantitative trait loci in the developing human brain and their enrichment in neuropsychiatric disorders. Genome Biology [Internet]. BioMed Central; 2018;19. Available from: /pmc/articles/PMC6231252/

99. Trampush JW, Yang MLZ, Yu J, Knowles E, Davies G, Liewald DC, et al. GWAS metaanalysis reveals novel loci and genetic correlates for general cognitive function: a report from the COGENT consortium. Molecular Psychiatry 2017 22:3. Nature Publishing Group; 2017;22:336-45.

100. Wei XT, Feng GJ, Zhang H, Xu Q, Ni JJ, Zhao M, et al. Pleiotropic genomic variants at 17q21.31 associated with bone mineral density and body fat mass: a bivariate genomewide association analysis. European Journal of Human Genetics 2020 29:4. Nature Publishing Group; 2020;29:553-63.

101. Bowles KR, Pugh DA, Farrell K, Han N, Tcw J, Liu Y, et al. 17q21.31 sub-haplotypes underlying $\mathrm{H} 1$-associated risk for Parkinson's disease are associated with LRRC37A/2 expression in astrocytes. bioRxiv. Cold Spring Harbor Laboratory; 2021;860668-860668. 
102. Boettger LM, Handsaker RE, Zody MC, Mccarroll SA. Structural haplotypes and recent evolution of the human 17q21.31 region. Nature genetics. NIH Public Access; 2012;44:881-881.

103. Guo H, Ahmed M, Zhang F, Yao CQ, Li S, Liang Y, et al. Modulation of long noncoding RNAs by risk SNPs underlying genetic predispositions to prostate cancer. Nat Genet. 2016;48:1142-50.

104. Michailidou K, Hall P, Gonzalez-Neira A, Ghoussaini M, Dennis J, Milne RL, et al. Largescale genotyping identifies 41 new loci associated with breast cancer risk. Nature Genetics. 2013;45:353-61.

105. Sirey TM, Roberts K, Haerty W, Bedoya-Reina O, Granados SR, Tan JY, et al. The long non-coding rna cerox1 is a post transcriptional regulator of mitochondrial complex $\mathrm{i}$ catalytic activity. eLife. eLife Sciences Publications Ltd; 2019;8.

106. Deng X, Zhao Y, Wang B. miR-519d-mediated downregulation of STAT3 suppresses breast cancer progression. Oncology reports. Oncol Rep; 2015;34:2188-94.

107. Li D, Song H, Wu T, Xie D, Hu J, Zhao J, et al. MiR-519d-3p suppresses breast cancer cell growth and motility via targeting LIM domain kinase 1. Molecular and cellular biochemistry. Mol Cell Biochem; 2018;444:169-78.

108. Feng H, Gusev A, Pasaniuc B, Wu L, Long J, Abu-full Z, et al. Transcriptome-wide association study of breast cancer risk by estrogen-receptor status. Genetic Epidemiology. John Wiley \& Sons, Ltd; 2020;44:442-68.

109. Gusev A, Lawrenson K, Lin X, Lyra PC, Kar S, Vavra KC, et al. A transcriptome-wide association study of high-grade serous epithelial ovarian cancer identifies new susceptibility genes and splice variants. Nature Genetics. Nature Publishing Group; 2019;51:815-23. 
110. Pashirzad M, Fiuji H, Khazei M, Moradi-Binabaj M, Ryzhikov M, Shabani M, et al. Role of Wnt3a in the pathogenesis of cancer, current status and prospective. Molecular Biology Reports. Springer Netherlands; 2019;46:5609-16.

111. Wu Y, Ginther C, Kim J, Mosher N, Chung S, Slamon D, et al. Expression of Wnt3 activates Wnt/ $\beta$-catenin pathway and promotes EMT-like phenotype in trastuzumabresistant HER2-overexpressing breast cancer cells. Molecular cancer research : MCR. Mol Cancer Res; 2012;10:1597-606.

112. Zhou JX, Yang X, Ning S, Wang L, Wang K, Zhang Y, et al. Identification of KANSARL as the first cancer predisposition fusion gene specific to the population of European ancestry origin. Oncotarget. Impact Journals, LLC; 2017;8:50594-50594.

113. Wu W, Li D, Feng X, Zhao F, Li C, Zheng S, et al. A pan-cancer study of selenoprotein genes as promising targets for cancer therapy. BMC Medical Genomics. BioMed Central Ltd; 2021;14:1-14.

114. Yu Y, Hu H, Doust AN, Kellogg EA. Divergent gene expression networks underlie morphological diversity of abscission zones in grasses. New Phytologist. 2019;nph.16087-nph.16087.

115. de Jong S, Chepelev I, Janson E, Strengman E, van den Berg LH, Veldink JH, et al. Common inversion polymorphism at 17q21.31 affects expression of multiple genes in tissue-specific manner. BMC Genomics. BioMed Central; 2012;13:1-6.

116. Lu Y, Beeghly-Fadiel A, Wu L, Guo X, Li B, Schildkraut JM, et al. A transcriptome-wide association study among 97,898 women to identify candidate susceptibility genes for epithelial ovarian cancer risk. Cancer Research. Cancer Res; 2018;78:5419-30.

117. Su X, Li W, Lv L, Li X, Yang J, Luo XJ, et al. Transcriptome-Wide Association Study Provides Insights Into the Genetic Component of Gene Expression in Anxiety. Frontiers in Genetics. Frontiers Media S.A.; 2021;12:1901-1901. 
medRxiv preprint doi: https://doi.org/10.1101/2022.02.08.22270601; this version posted February 23, 2022. The copyright holder for this preprint (which was not certified by peer review) is the author/funder, who has granted medRxiv a license to display the preprint in perpetuity.

It is made available under a CC-BY 4.0 International license .

840

841

842

843

844

845

846

847

848

849

850

851

852

853

854

855

856

857

858

859

860

861

862

863

864

865

118. Lee CT, Bendriem RM, Kindberg AA, Worden LT, Williams MP, Drgon T, et al. Functional Consequences of 17q21.31/WNT3-WNT9B Amplification in hPSCs with Respect to Neural Differentiation. Cell Reports. Cell Press; 2015;10:616-32.

119. Zhang D, Guelfi S, Garcia-Ruiz S, Costa B, Reynolds RH, D’Sa K, et al. Incomplete annotation has a disproportionate impact on our understanding of Mendelian and complex neurogenetic disorders. Science Advances. American Association for the Advancement of Science; 2020;6:8299-8299.

120. Giambartolomei C, Liu JZ, Zhang W, Hauberg M, Shi H, Boocock J, et al. A Bayesian framework for multiple trait colocalization from summary association statistics. Bioinformatics. Oxford University Press; 2018;34:2538-45.

121. Gleason KJ, Yang F, Pierce BL, He X, Chen LS. Primo: Integration of multiple GWAS and omics QTL summary statistics for elucidation of molecular mechanisms of trait-associated SNPs and detection of pleiotropy in complex traits. Genome Biology. BioMed Central Ltd; $2020 ; 21: 236-236$.

122. Bhattacharya A, García-Closas M, Olshan AF, Perou CM, Troester MA, Love MI. A framework for transcriptome-wide association studies in breast cancer in diverse study populations. Genome Biology. BioMed Central; 2020;21:42-42.

123. Geeleher P, Nath A, Wang F, Zhang Z, Barbeira AN, Fessler J, et al. Cancer expression quantitative trait loci (eQTLs) can be determined from heterogeneous tumor gene expression data by modeling variation in tumor purity. Genome Biology. BioMed Central; 2018;19:130-130.

124. Patel A, Garcia-Closas M, Olshan AF, Perou CM, Troester MA, Love MI, et al. Gene level germline contributions to clinical risk of recurrence scores in Black and White breast cancer patients. Cancer Research. American Association for Cancer Research; 2021 ;canres.1207.2021-canres.1207.2021. 
medRxiv preprint doi: https://doi.org/10.1101/2022.02.08.22270601; this version posted February 23, 2022. The copyright holder for this preprint (which was not certified by peer review) is the author/funder, who has granted medRxiv a license to display the preprint in perpetuity.

It is made available under a CC-BY 4.0 International license .

866

867

868

869

870

871

872

873

874

875

876

877

878

879

880

881

882

883

884

885

886

887

888

889

890

\section{ACKNOWLEDGEMENTS}

We thank Nicholas Mancuso, Harold Pimentel, Mike Love, Achal Patel, and Kangcheng Hou for engaging conversation during the research process. We also thank the UCLA Bruins-in-

Genomics Summer Program for the research opportunities.

The Prostate cancer genome-wide association analyses are supported by the Canadian Institutes of Health Research, European Commission's Seventh Framework Programme grant agreement n²23175 (HEALTH-F2-2009-223175), Cancer Research UK Grants C5047/A7357, C1287/A10118, C1287/A16563, C5047/A3354, C5047/A10692, C16913/A6135, and The National Institute of Health (NIH) Cancer Post-Cancer GWAS initiative grant: No. 1 U19 CA 148537-01 (the GAME-ON initiative).

Genotyping of the OncoArray was funded by the US National Institutes of Health (NIH) [U19 CA 148537 for ELucidating Loci Involved in Prostate cancer SuscEptibility (ELLIPSE) project and X01HG007492 to the Center for Inherited Disease Research (CIDR) under contract number HHSN268201200008I] and by Cancer Research UK grant A8197/A16565. Additional analytic support was provided by NIH NCI U01 CA188392 (PI: Schumacher).

We would also like to thank the following for funding support: The Institute of Cancer Research and The Everyman Campaign, The Prostate Cancer Research Foundation, Prostate Research Campaign UK (now PCUK), The Orchid Cancer Appeal, Rosetrees Trust, The National Cancer Research Network UK, The National Cancer Research Institute (NCRI) UK. We are grateful for support of NIHR funding to the NIHR Biomedical Research Centre at The Institute of Cancer Research and The Royal Marsden NHS Foundation Trust. 
medRxiv preprint doi: https://doi.org/10.1101/2022.02.08.22270601; this version posted February 23, 2022. The copyright holder for this preprint (which was not certified by peer review) is the author/funder, who has granted medRxiv a license to display the preprint in perpetuity.

It is made available under a CC-BY 4.0 International license .

The breast cancer genome-wide association analyses for BCAC and CIMBA were supported by Cancer Research UK (C1287/A10118, C1287/A16563, C1287/A10710, C12292/A20861, C12292/A11174, C1281/A12014, C5047/A8384, C5047/A15007, C5047/A10692, C8197/A16565), The National Institutes of Health (CA128978, X01HG007492- the DRIVE consortium), the PERSPECTIVE project supported by the Government of Canada through Genome Canada and the Canadian Institutes of Health Research (grant GPH-129344) and the Ministère de l'Économie, Science et Innovation du Québec through Genome Québec and the PSRSIIRI-701 grant, the Quebec Breast Cancer Foundation, the European Community's Seventh Framework Programme under grant agreement n²23175 (HEALTH-F2-2009-223175) (COGS), the European Union's Horizon 2020 Research and Innovation Programme (634935 and 633784), the Post-Cancer GWAS initiative (U19 CA148537, CA148065 and CA148112 the GAME-ON initiative), the Department of Defence (W81XWH-10-1-0341), the Canadian Institutes of Health Research (CIHR) for the CIHR Team in Familial Risks of Breast Cancer (CRN-87521), the Komen Foundation for the Cure, the Breast Cancer Research Foundation and the Ovarian Cancer Research Fund. All studies and funders are listed in Zhang $\mathrm{H}$ et al (Nat Genet, 2020).

\section{FUNDING}

TS was supported by the National Institute of Neurological Disorders and Stroke of the National Institutes of Health under Award Number T32NS048004. This research was supported by the National Institute of Mental Health of the National Institutes of Health under Award number 5R01MH115676-04. AG was partially supported by R01 CA227237. SL was partially supported by NIH award R01 CA194393. BP were partially supported by NIH awards R01 HG009120, R01 MH115676, R01 CA251555, R01 Al153827, R01 HG006399, R01 CA244670, U01 HG011715. The content is solely the responsibility of the authors and does not necessarily represent the official views of the National Institutes of Health. 


\section{AUTHOR INFORMATION}

919 Contributions

920 AB conceived the study. AB, TS, and PL developed the statistical approaches, performed the

921 analysis, and drafted the paper. AB, TS, and BP provided insight in methodological approaches

922 and analysis. BP provided data resources. AB and BP supervised the study. All authors

923 approved and edited the final manuscript.

924

925 Corresponding author

926 Correspondence to Arjun Bhattacharya (abtbhatt@ucla.edu)

927

\section{ETHICS DECLARATION}

929 Ethics approval and consent to participate

930 This study was approved by the Office of Human Research Ethics at the University of California,

931 Los Angeles, and written informed consent was obtained from each participant. All experimental

932 methods abided by the Helsinki Declaration.

933

934 Consent for publication

935 Not applicable.

936

937 Competing interests

938 The authors declare that they have no competing interests. 


\section{FIGURES}

Regulation via potential gene activation/inhibition

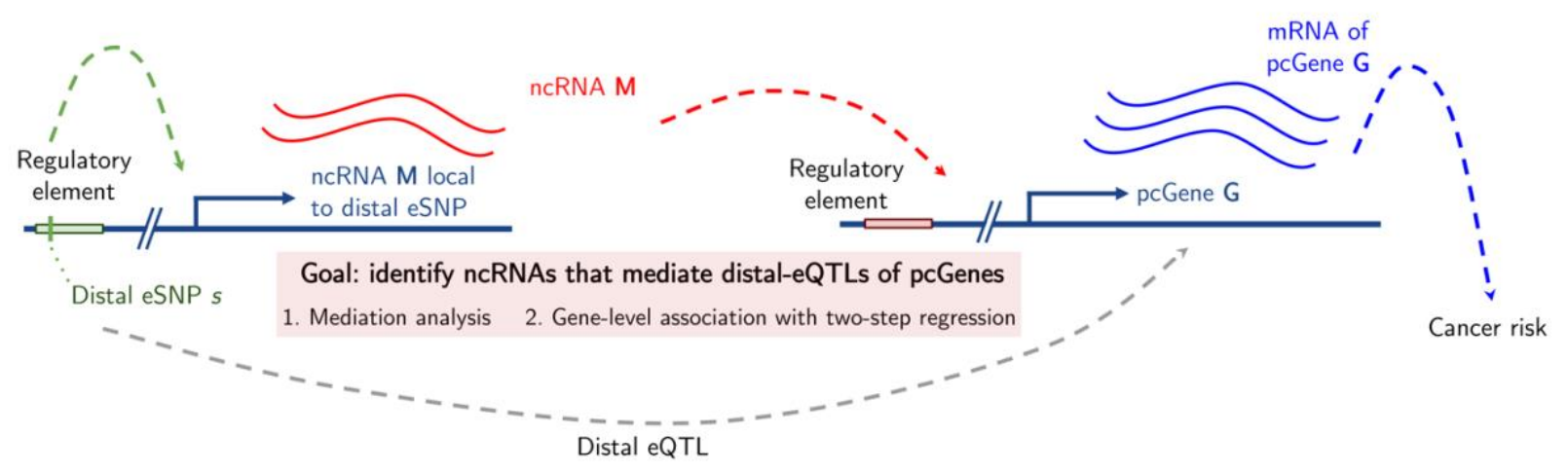

Figure 1: Schematic of mediation analysis to identify ncRNA-mediated distal-eQTLs of proteincoding genes. A SNP $\mathrm{s}$ is distal to protein-coding gene $\mathrm{G}$ and local to ncRNA $\mathrm{M}$, where $\mathrm{M}$ has some distal regulatory effect on $\mathrm{G}$. We use expression quantitative trait locus mapping to identify the local-eQTL between s and M (green dotted line) and the distal-eQTL between s and $\mathrm{G}$ (grey dotted line). Using either mediation analysis or gene-level association testing, we estimate the indirect mediation effect of $s$ on $G$ through effects from $M$ (red line). Lastly, we use colocalization and genetically-regulated expression analysis to find any intersecting genetic signal between distal-eQTLs of G and genetic associations with breast and prostate cancer risk. 
a

Distal-eQTLs from mediation analysis

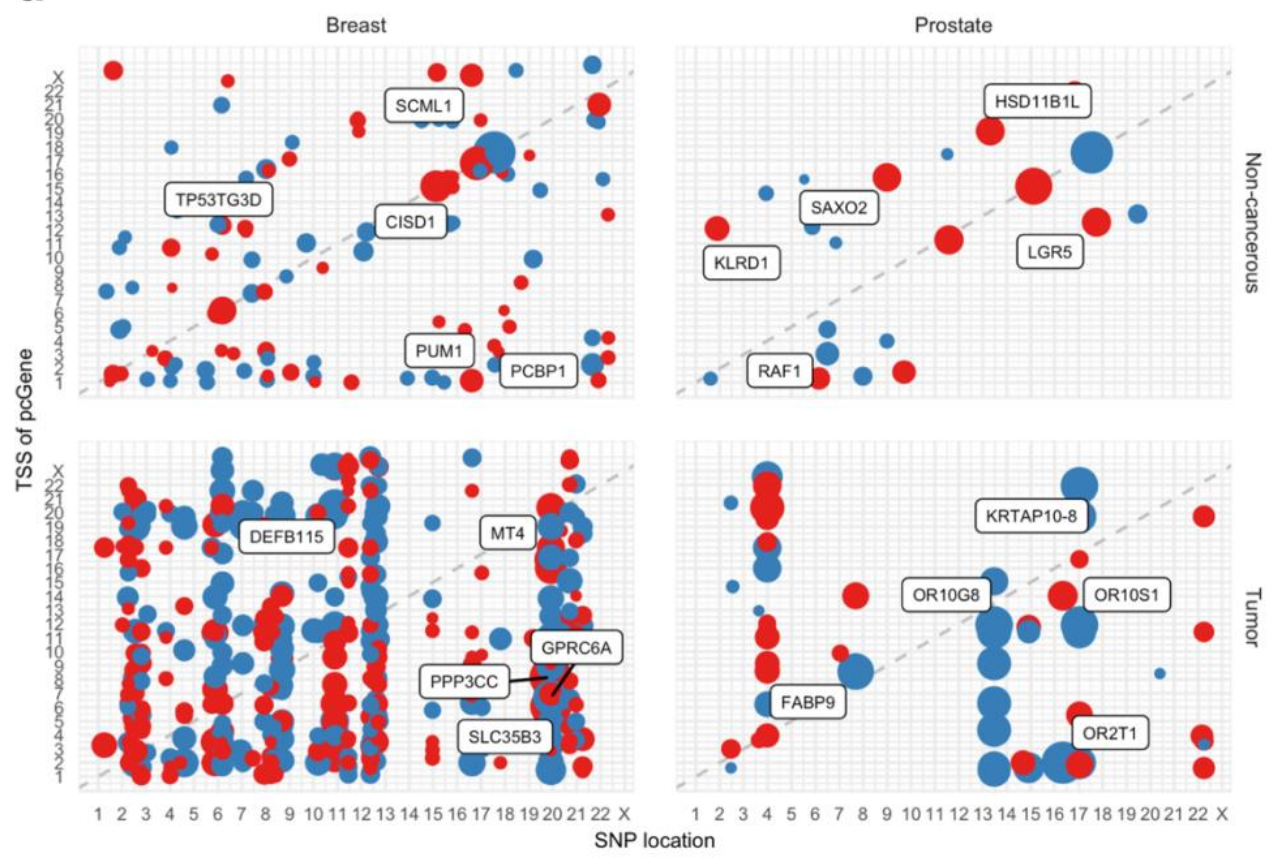

b Distal gene-gene associations from GBAT

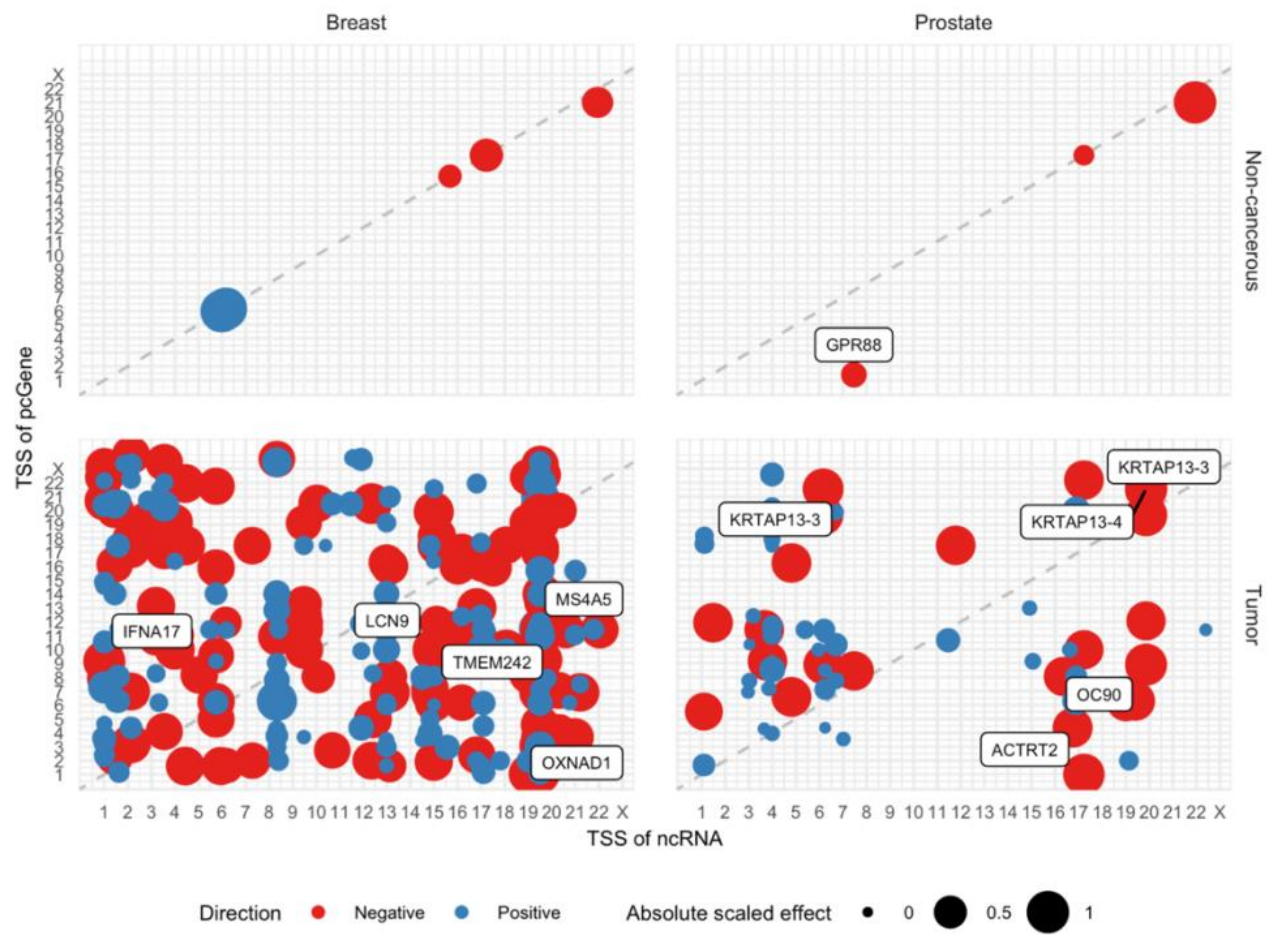

Figure 2: Location plot of distal-eQTL or gene-gene associations across healthy and tumor samples of breast and prostate tissue. (a) eSNP (X-axis) position vs. transcription start site (TSS) of pcGene (Y-axis) at FDR-adjusted $\mathrm{P}<0.01$, sized by absolute scaled TME and colored by direction of effect. (b) ncRNA TSS (X-axis) vs. pcGene TSS (Y-axis) at FDR-adjusted $\mathrm{P}<$ 0.01 , sized by absolute scaled gene-gene effect and colored by direction of effect. Top crosschromosomal distal-eGenes with largest effects are labeled. 
medRxiv preprint doi: https://doi.org/10.1101/2022.02.08.22270601; this version posted February 23, 2022. The copyright holder for this preprint (which was not certified by peer review) is the author/funder, who has granted medRxiv a license to display the preprint in perpetuity.

It is made available under a CC-BY 4.0 International license.

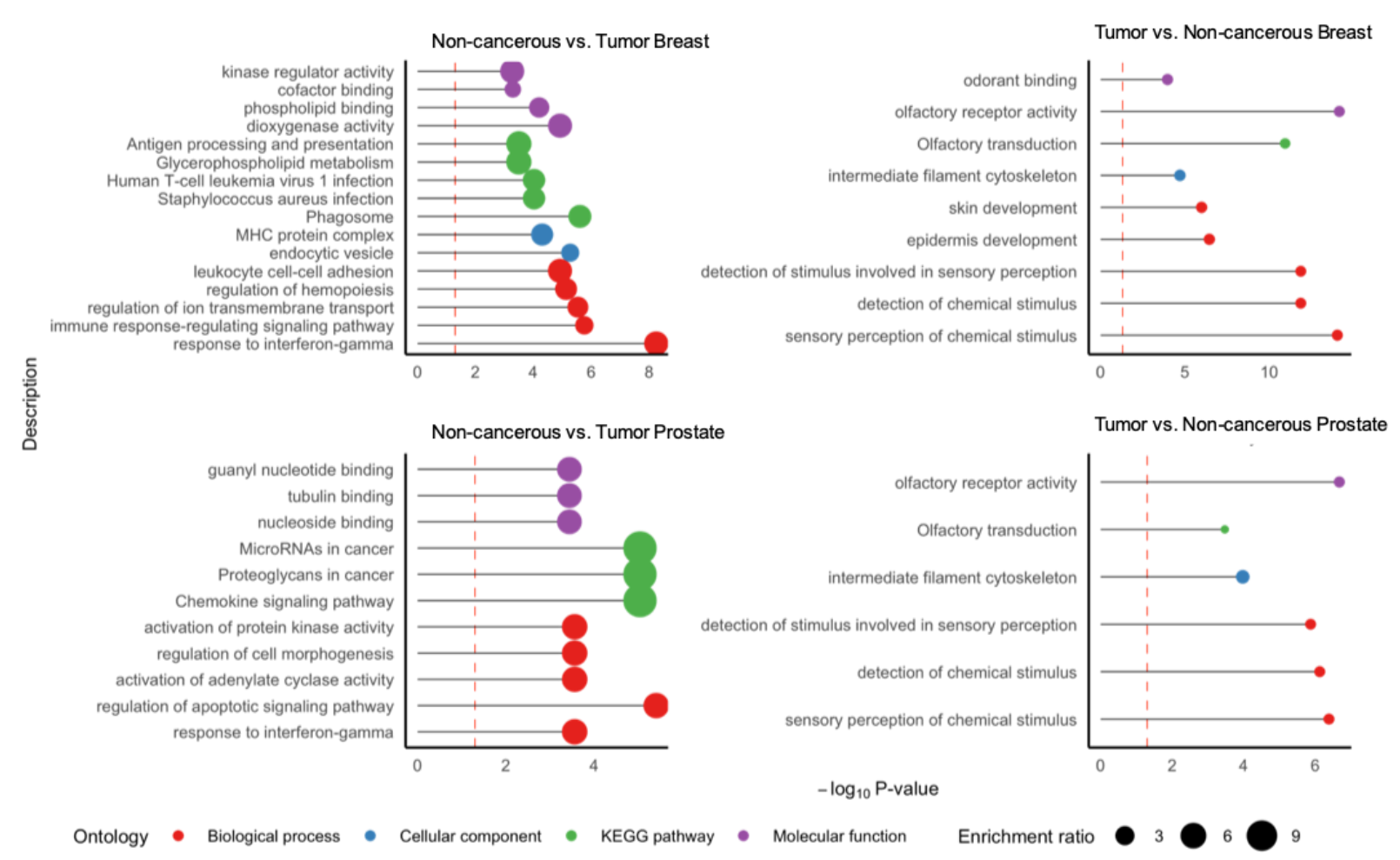

Figure 3: Over-represented ontologies for tissue-specific eGenes. - $\log _{10}$ P-value of enrichment (X-axis) of over-represented gene sets (Y-axis), with point sized by enrichment ratio and colored by ontology category. Here, for a tissue, we compare the set of pcGenes from healthy or tumor state to the universe of all pcGenes for tissue across both healthy and tumor states. 
medRxiv preprint doi: https://doi.org/10.1101/2022.02.08.22270601; this version posted February 23, 2022. The copyright holder for this preprint (which was not certified by peer review) is the author/funder, who has granted medRxiv a license to display the preprint in perpetuity.

It is made available under a CC-BY 4.0 International license .
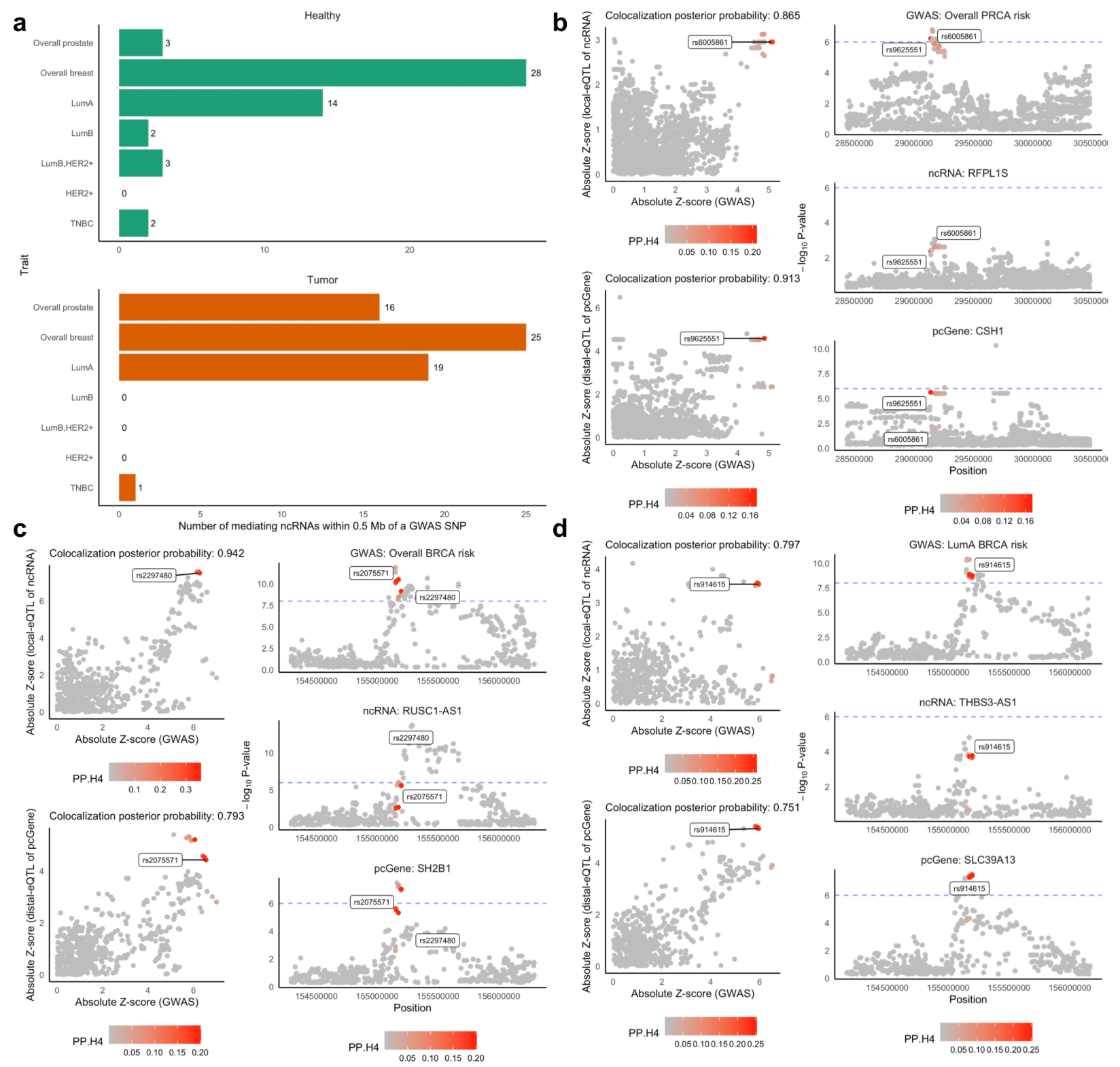

Figure 4: Colocalization of local-eQTLs of ncRNA and distal-eQTLs of pcGene with GWAS. (a) Barplot of numbers of mediating ncRNAs within 1 Megabase of a GWAS SNP (X-axis) from cancers (Y-axis). (b-d) Colocalization results for example ncRNAs and pcGenes, with phenotype in the GWAS, ncRNA, and pcGene provided. Left panel shows scatterplot of absolute Z-scores of GWAS (X-axis) and eQTL associations (Y-axis) with points colored by posterior probability of colocalization (PP.H4). Right panel shows a Manhattan plot of GWAS (top), ncRNA local-eQTL (middle), and pcGene distal-eQTL (bottom) signal, colored by PP.H4. 


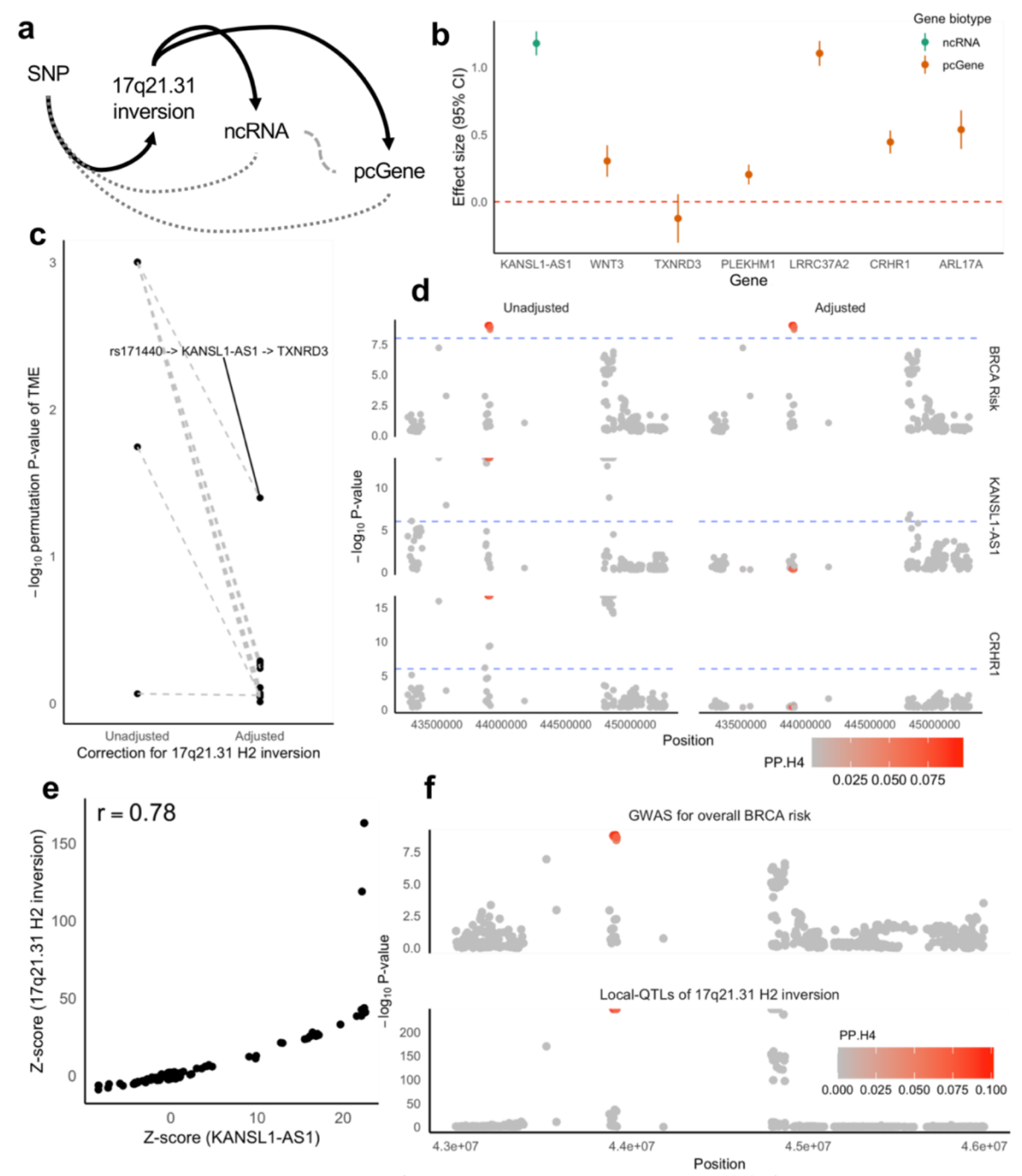

Figure 5: Impact of H2 inversion on eQTLs in the 17q21.31 locus. (a) Causal diagram of genetic effects in 17q21.31, where strong effects of genetically-determined $\mathrm{H} 2$ inversion on ncRNA and pcGene (in black) induces the observed SNP-ncRNA and -pcGene associations (in grey). (b) Forest plot of effect sizes and 95\% confidence interval ( $Y$-axis) on $\mathrm{H} 2$ inversion on pcGenes or ncRNAs (X-axis). (c) Difference in -log10 permutation P-value (Y-axis) of total mediation effect of ncRNA on pcGene, with or without adjustment for $\mathrm{H} 2$ inversion (X-axis). (d) Manhattan plots of GWAS, local-eQTLs of KANSL-AS1, and distal-eQTLs of CRHR1, unadjusted (left) and adjusted (right) for $\mathrm{H} 2$ inversion, colored by per-SNP PP.H4. (e) Scatterplot of Z-score of local-eQTLs on KANSL1-AS1 (X-axis) against Z-score of local-QTLs of $\mathrm{H} 2$ inversion. (f) Manhattan plots of GWAS and local-QTLs of $\mathrm{H} 2$ inversion, colored by per-SNP PP.H4. 
medRxiv preprint doi: https://doi.org/10.1101/2022.02.08.22270601; this version posted February 23, 2022. The copyright holder for this preprint (which was not certified by peer review) is the author/funder, who has granted medRxiv a license to display the preprint in perpetuity.

It is made available under a CC-BY 4.0 International license.

a
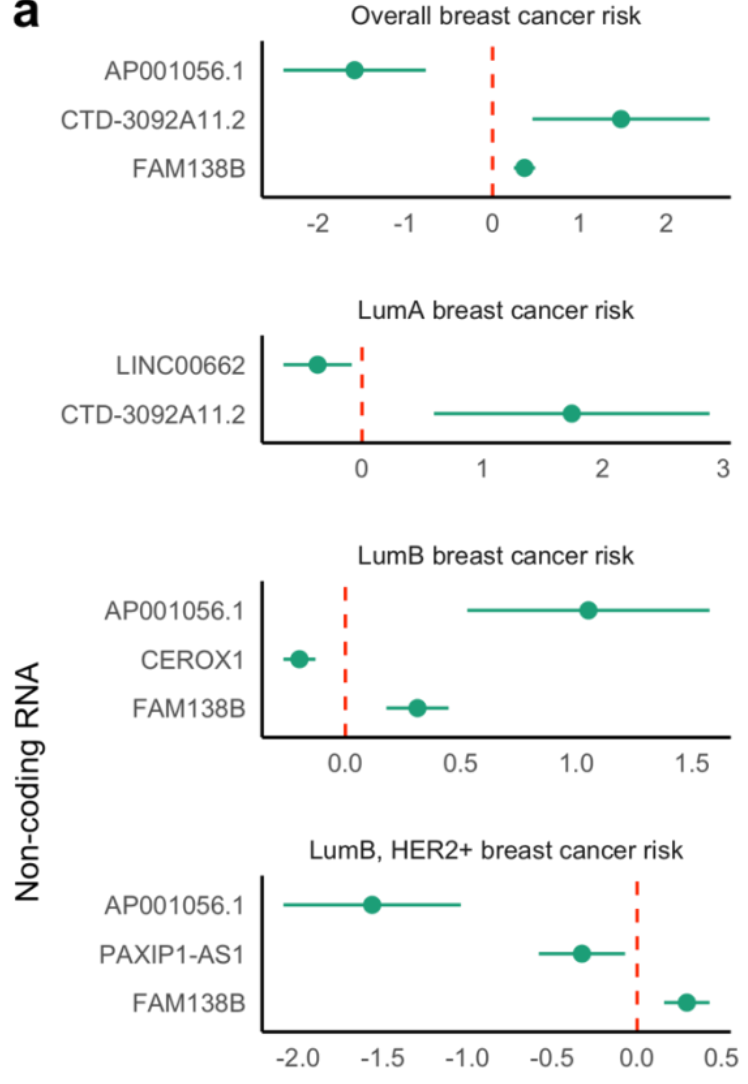

HER2 + breast cancer risk

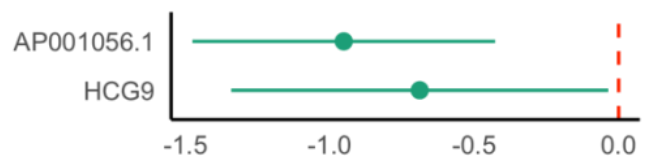

TNBC breast cancer risk

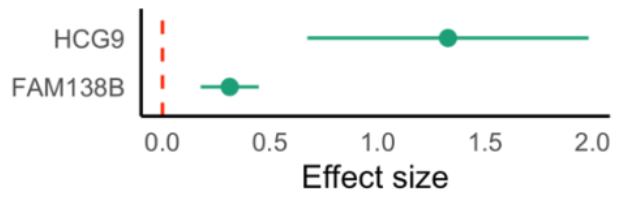

b
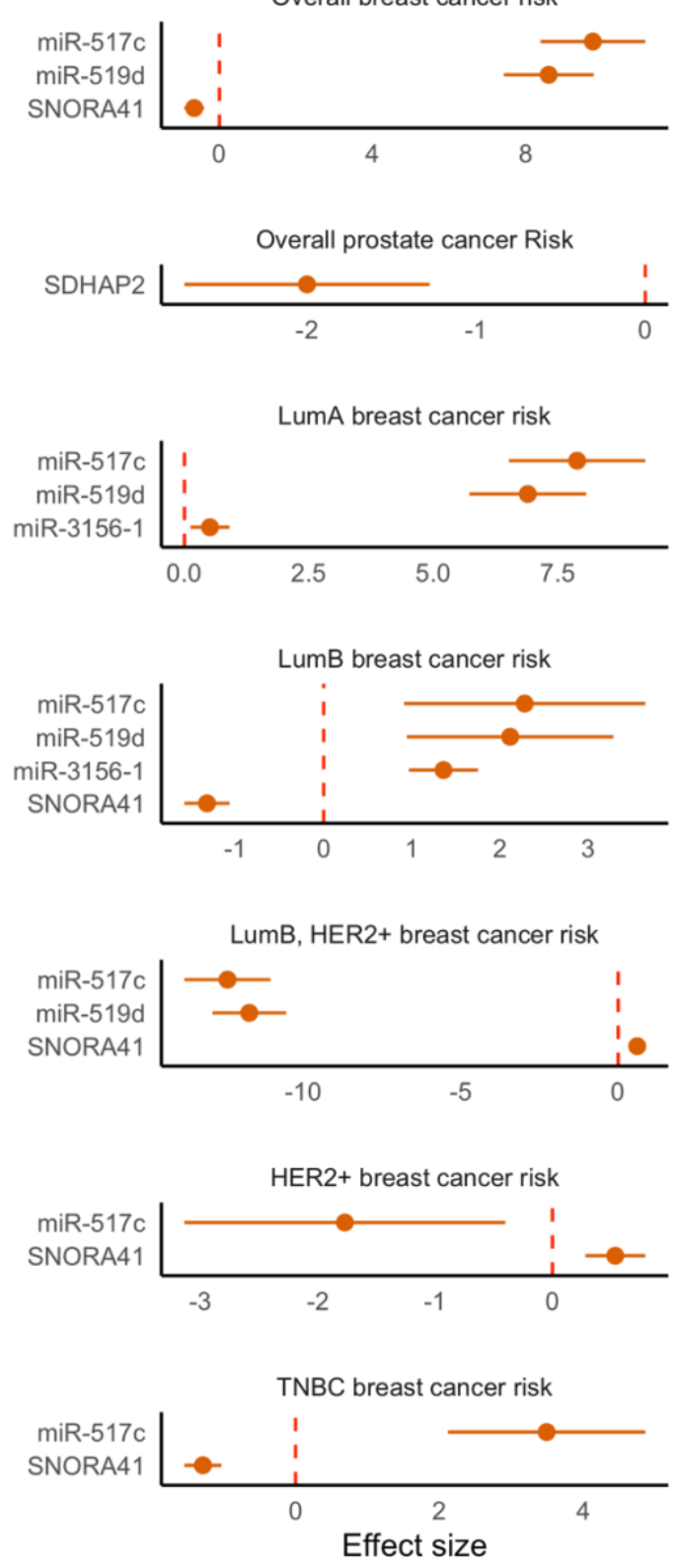

Tissue state $\phi$ Non-cancerous $\phi$ Tumor

Figure 6: GReX associations with cancer risk for ncRNAs mediating multiple distal-eQTLs of pcGenes. Forest plot of effect size and confidence intervals at significance level of $\mathrm{P}=2.5 \times 10^{-6}$ (Y-axis) of GReX-associations with overall and subtype-specific cancer risk across ncRNAs that showed significant mediation of multiple distal-eQTLs of distinct pcGenes (X-axis) in noncancerous (a) and tumor (b) tissue states. 
medRxiv preprint doi: https://doi.org/10.1101/2022.02.08.22270601; this version posted February 23, 2022. The copyright holder for this preprint (which was not certified by peer review) is the author/funder, who has granted medRxiv a license to display the preprint in perpetuity.

It is made available under a CC-BY 4.0 International license.

\section{TABLES}

Table 1: Summary of local- and distal-eQTL mapping results across breast and prostate noncancerous and tumor tissue through mediation analysis.

\begin{tabular}{|c|c|c|c|c|}
\hline & \multicolumn{2}{|c|}{ Breast } & \multicolumn{2}{|c|}{ Prostate } \\
\hline Total eQTLs & $\begin{array}{c}\text { Non- } \\
\text { cancerous }\end{array}$ & Tumor & $\begin{array}{c}\text { Non- } \\
\text { cancerous }\end{array}$ & Tumor \\
\hline Local & 22,832 & 1,298 & 12,511 & 6,368 \\
\hline Distal & 29,512 & 316,097 & 31,782 & 363,587 \\
\hline Total eGenes & & & & \\
\hline local-ncRNAs & 1,113 & 87 & 773 & 60 \\
\hline distal-pcGenes & 8,849 & 19,376 & 8,711 & 15,560 \\
\hline $\begin{array}{l}\text { SNPs associated in both local and distal } \\
\text { eQTLS }\end{array}$ & & & & \\
\hline Local & 1,569 & 601 & 281 & 6,368 \\
\hline Distal & 1,580 & 5,089 & 264 & 9,259 \\
\hline Mediated distal-eQTLs & & & & \\
\hline eSNPS & 703 & 3,017 & 103 & 425 \\
\hline$e-n c R N A s$ & 157 & 45 & 22 & 18 \\
\hline e-pcGenes & 173 & 562 & 24 & 107 \\
\hline
\end{tabular}


medRxiv preprint doi: https://doi.org/10.1101/2022.02.08.22270601; this version posted February 23, 2022. The copyright holder for this preprint (which was not certified by peer review) is the author/funder, who has granted medRxiv a license to display the preprint in perpetuity.

It is made available under a CC-BY 4.0 International license .

Table 2: Summary of distal-eQTL mapping results across breast and prostate normal and tumor tissue using GBAT.

\begin{tabular}{r|cc|cc} 
& \multicolumn{2}{|c|}{ Breast } & \multicolumn{2}{c}{ Prostate } \\
\hline Total gene-gene & Normal & Tumor & Normal & Tumor \\
associations & 13 & 1,375 & 7 & 297 \\
Unique ncRNAs & 9 & 209 & 4 & 84 \\
Unique pcGenes & 10 & 1,127 & 5 & 268
\end{tabular}




\section{SUPPLEMENTAL FIGURES}

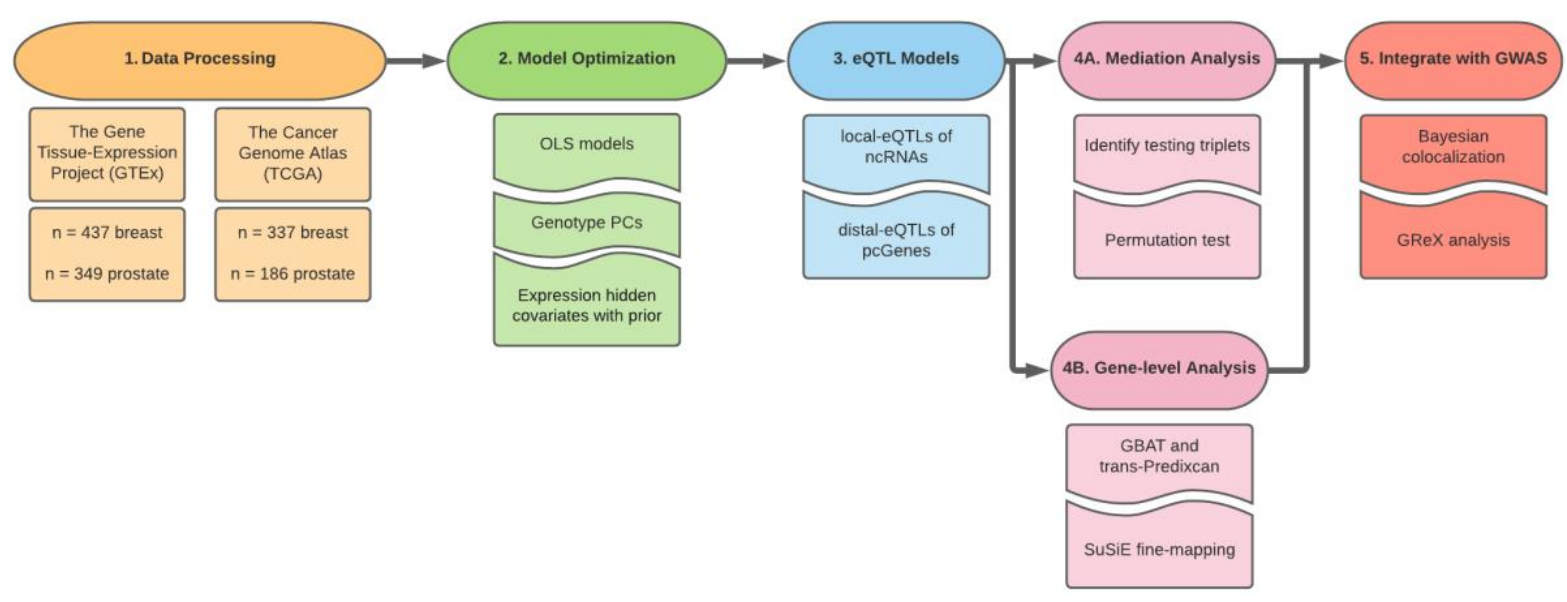

Supplemental Figure S1: Analysis scheme. We analyze genetic and transcriptomic data from non-cancerous breast and prostate tissue from GTEx and breast and prostate tumors from TCGA. We optimize eQTL mapping using ordinary least squares regression for numbers of genotype principal components and expression hidden covariates with prior to optimize eQTL discovery. We then conduct a genome-wide local and distal eQTL analysis using the optimized set of covariates. Next, we conduct mediation analysis or gene-based association testing to identify distal-eQTLs of pcGenes that are mediated by local-eQTLs of ncRNAs. Lastly, we integrate eQTLs results with GWAS using colocalization and analysis of genetically-regulated expression. 

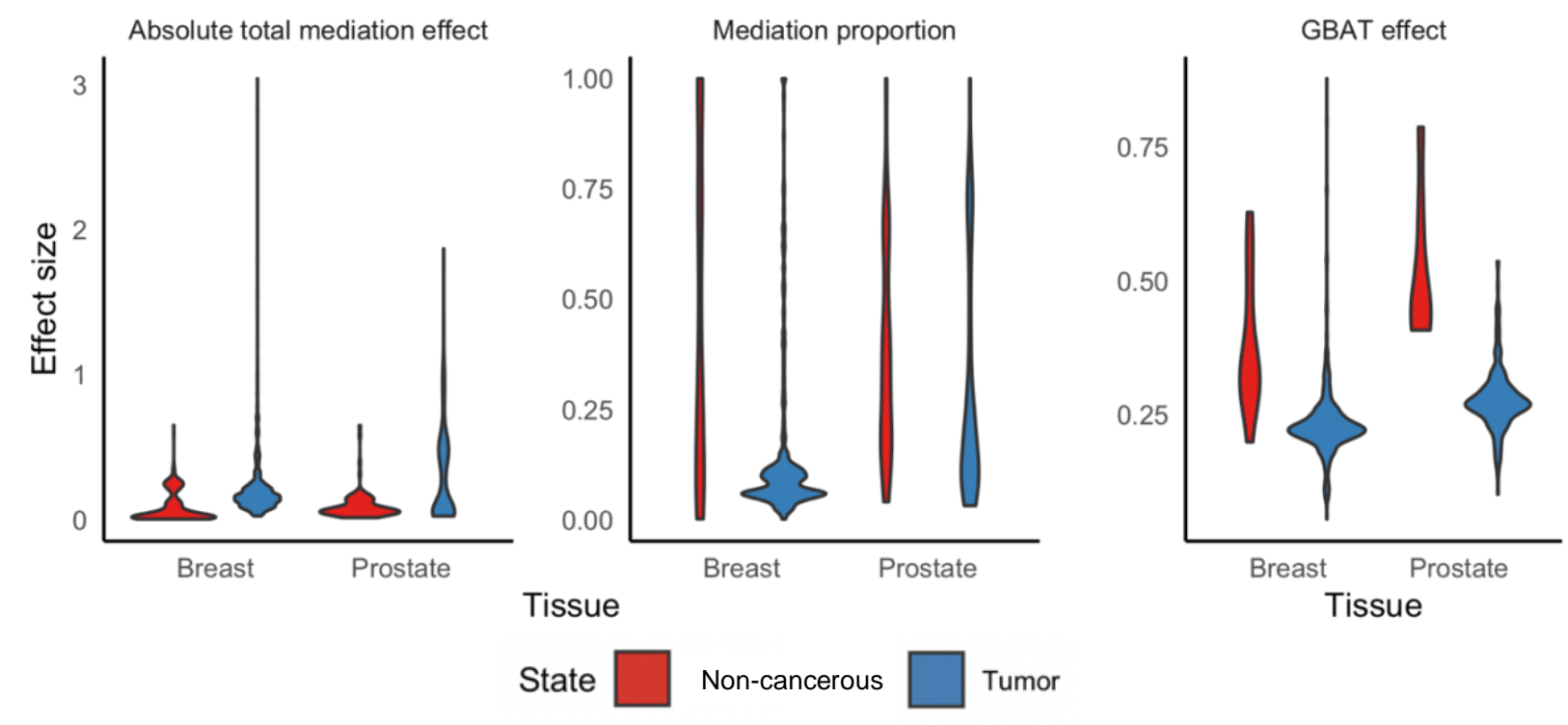

Supplemental Figure S2: Distribution of total mediation effects, mediation proportions, and gene-level distal effect sizes in healthy and tumor breast and prostate tissue. 
medRxiv preprint doi: https://doi.org/10.1101/2022.02.08.22270601; this version posted February 23, 2022. The copyright holder for this preprint (which was not certified by peer review) is the author/funder, who has granted medRxiv a license to display the preprint in perpetuity.

It is made available under a CC-BY 4.0 International license.

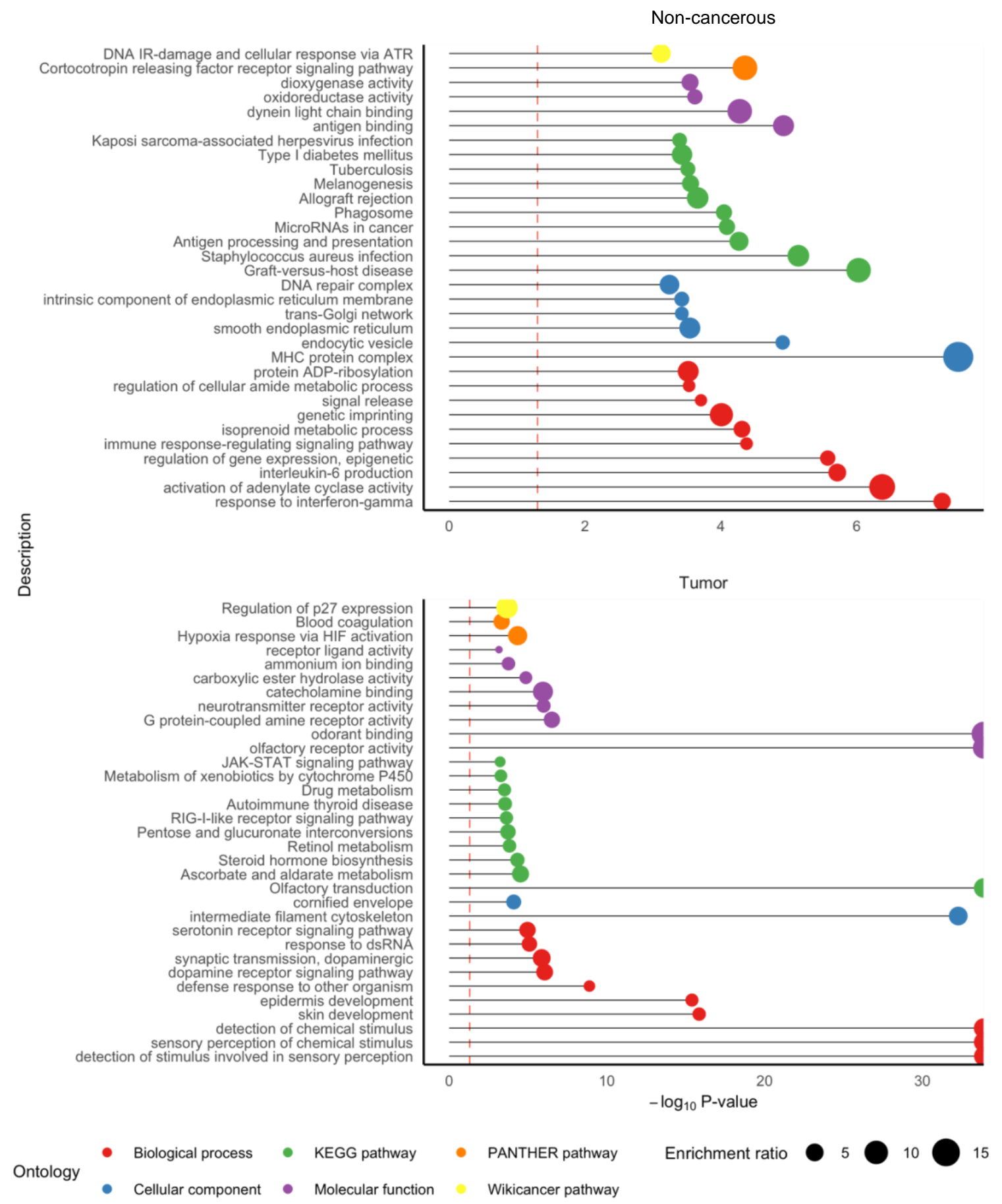

Supplemental Figure S3: Over-represented ontologies for healthy- or tumor-specific eGenes, compared to all protein-coding genes in the transcriptome. - $\log _{10} \mathrm{P}$-value of enrichment (X-axis) of over-represented gene sets (Y-axis), with point sized by enrichment ratio and colored by ontology category. Here, combining pcGenes with a distal genetic association across breast and prostate tissue, we compare the set of pcGenes from healthy or tumor state to the universe of all pcGenes in the transcriptome. 
medRxiv preprint doi: https://doi.org/10.1101/2022.02.08.22270601; this version posted February 23, 2022. The copyright holder for this preprint (which was not certified by peer review) is the author/funder, who has granted medRxiv a license to display the preprint in perpetuity.

It is made available under a CC-BY 4.0 International license .

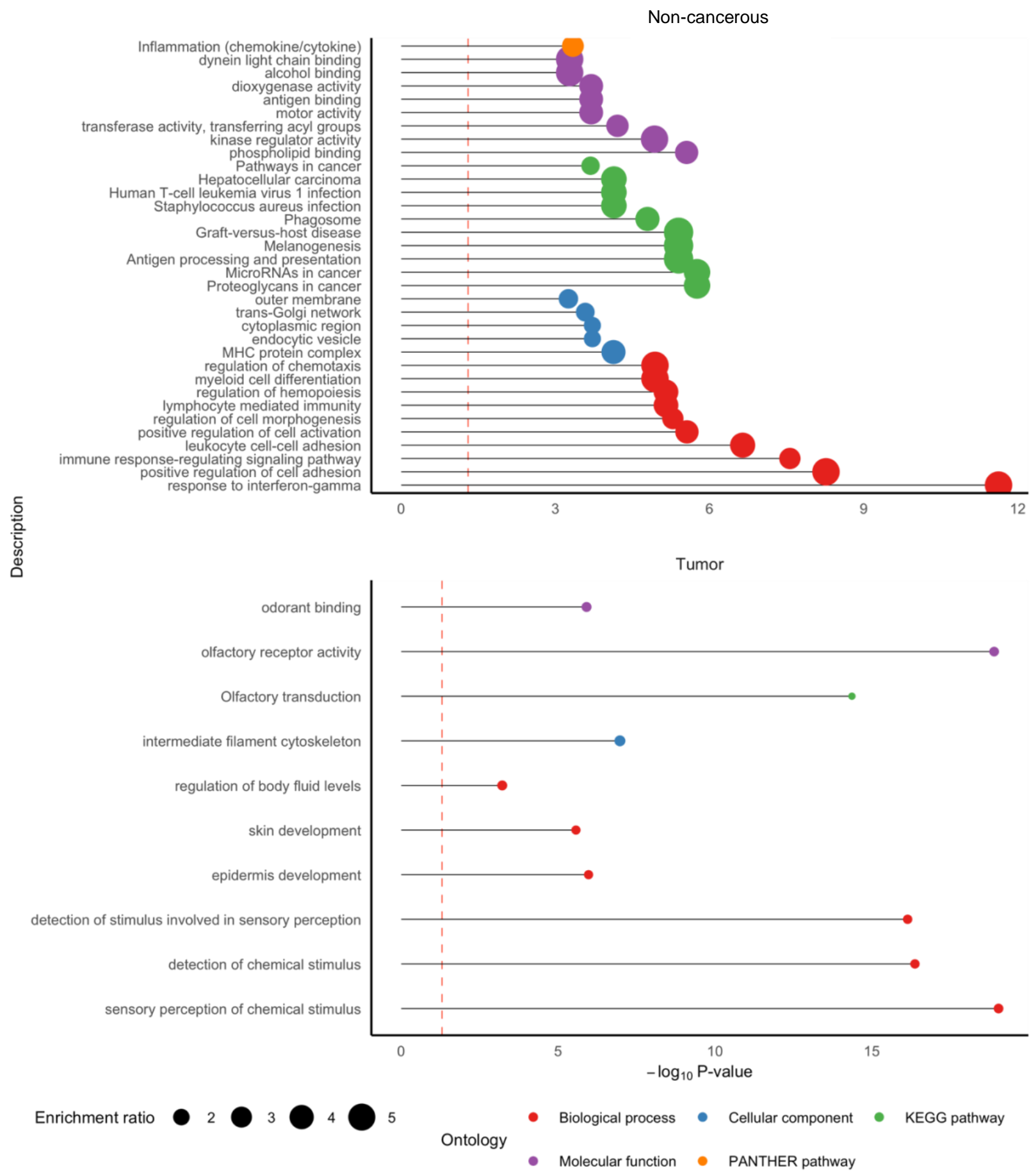

Supplemental Figure S4: Over-represented ontologies for healthy or tumor state-specific eGenes, compared to all protein-coding genes detected in distal-QTL mapping. - $\log _{10}$ P-value of enrichment (X-axis) of over-represented gene sets (Y-axis), with point sized by enrichment ratio and colored by ontology category. Here, combining pcGenes with a distal genetic association across breast and prostate tissue, we compare the set of pcGenes detected for breast or prostate and compare to the universe of all pcGenes detected across breast and prostate. No enrichments at $P<0.05$ were detected for breast-specific pcGenes. 
medRxiv preprint doi: https://doi.org/10.1101/2022.02.08.22270601; this version posted February 23, 2022. The copyright holder for this preprint (which was not certified by peer review) is the author/funder, who has granted medRxiv a license to display the preprint in perpetuity.

It is made available under a CC-BY 4.0 International license.

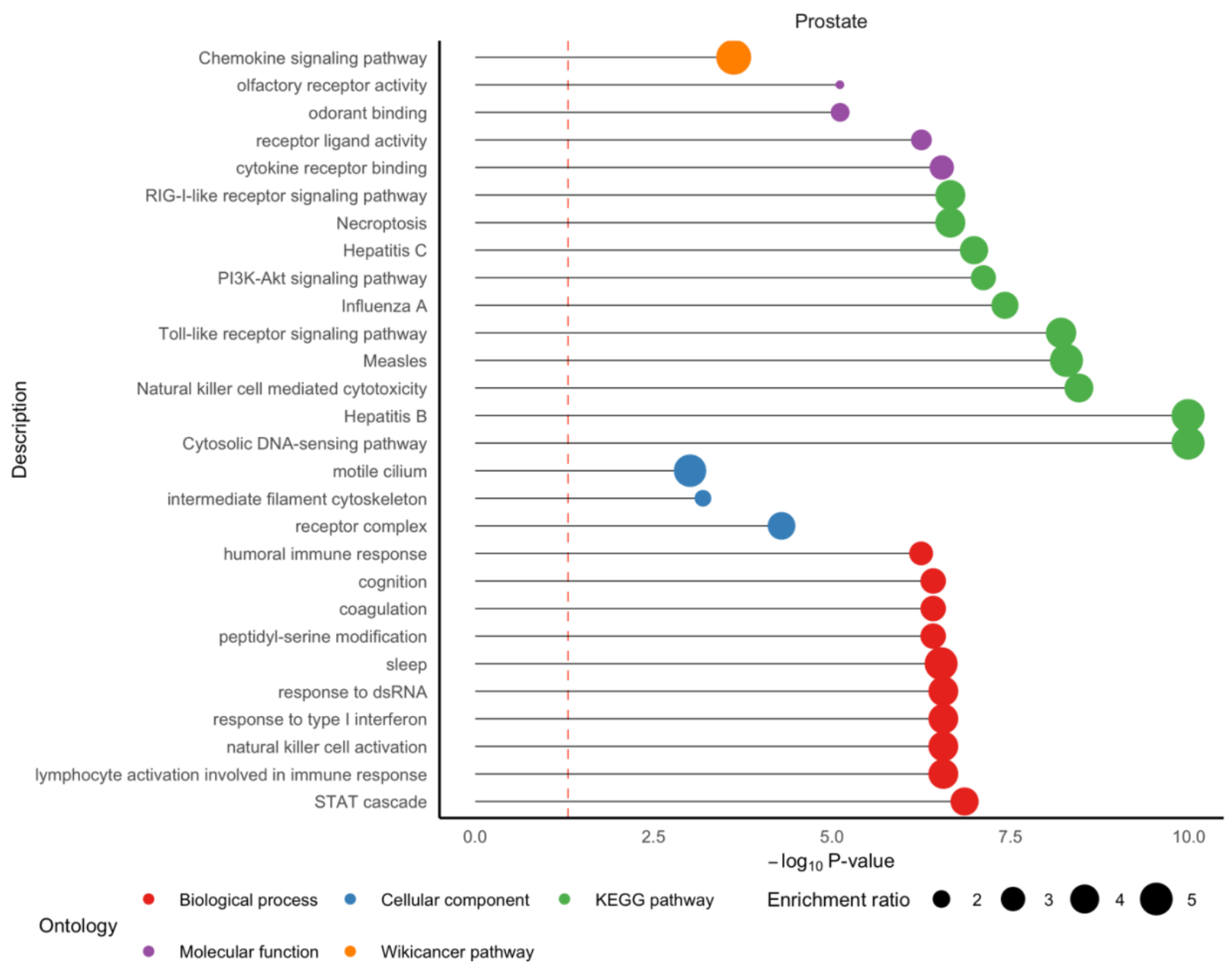

Supplemental Figure S5: Over-represented ontologies for breast or prostate-specific eGenes, compared to all protein-coding genes detected in distal-QTL mapping. - $\log _{10} \mathrm{P}$-value of enrichment (X-axis) of over-represented gene sets (Y-axis), with point sized by enrichment ratio and colored by ontology category. Here, combining pcGenes with a distal genetic association across healthy and tumor state, we compare the set of pcGenes detected for breast or prostate and compare to the universe of all pcGenes detected across breast and prostate. No enrichments at $P<0.05$ were detected for breast-specific pcGenes. 


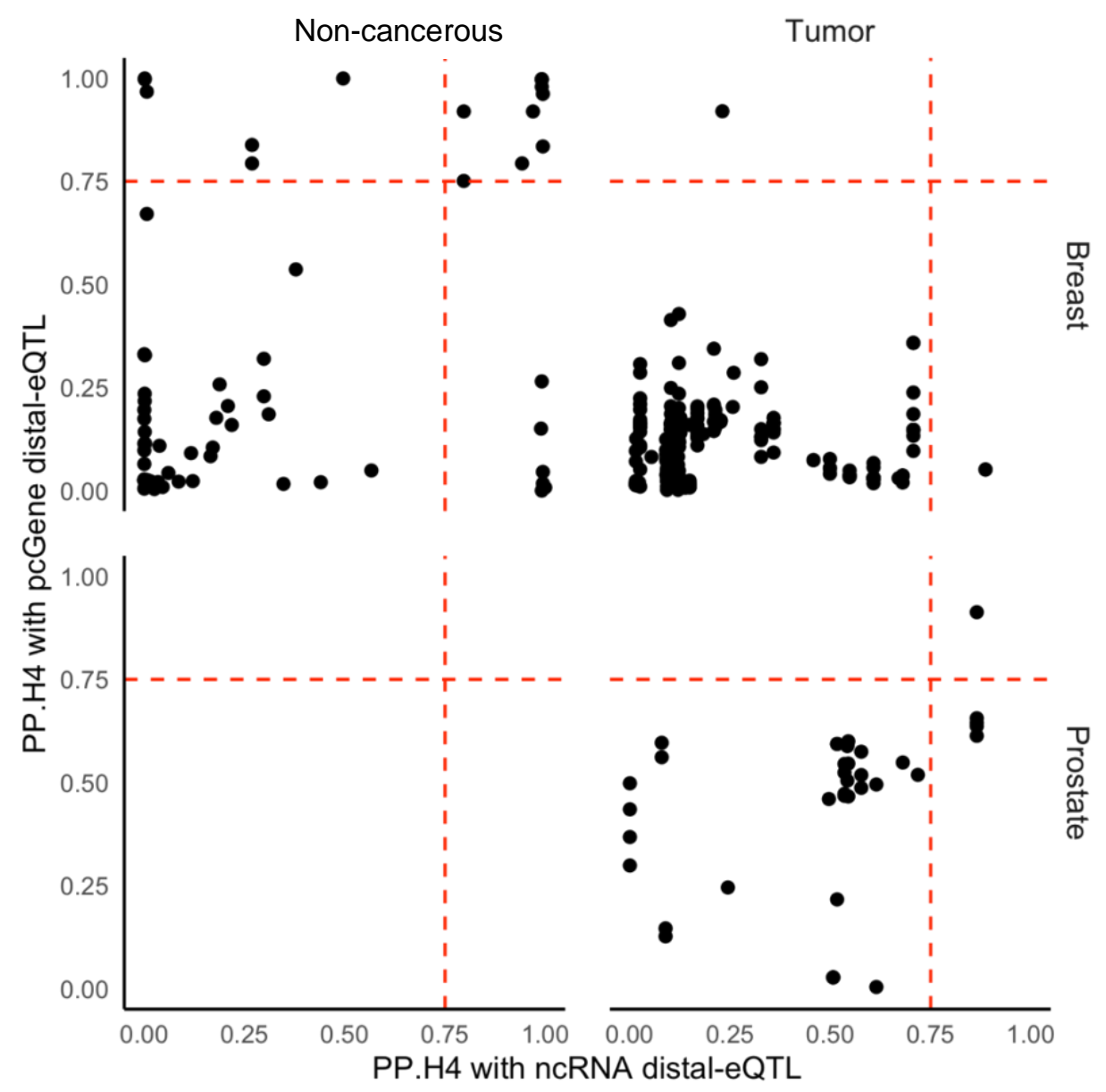

Supplemental Figure S6: Scatterplot of posterior probability of colocalization for local- and distal-eQTLs with cancer risk GWAS. Red lines show PP.H4 = .75. 


\section{SUPPLEMENTAL TABLE LEGENDS}

Table S1: Prioritized ncRNA-mediated distal-eQTLs of pcGenes in healthy and tumor prostate tissue. We provide the tissue state (healthy or tumor), SNP, ncRNA, pcGene, effect size, Pvalue, method of detection (mediation analysis or GBAT), and closest GWAS risk SNP and Pvalue.

Table S2: Prioritized ncRNA-mediated distal-eQTLs of pcGenes in healthy and tumor breast tissue. We provide the tissue state (healthy or tumor), SNP, ncRNA, pcGene, effect size, Pvalue, method of detection (mediation analysis or GBAT), and closest GWAS risk SNP and Pvalue.

Table S3: In-silico validation of miRNA-pcGene pairs using TargetScan. For miRNAs detected to mediated distal-eQTLs of pcGenes, we list miRNAs shown to target the pcGene using TargetScan.

Table S4: Colocalization results for ncRNA-mediated distal-eQTLs with GWAS signal of cancer risk. We provide the trait, tissue (breast or prostate), tissue state (healthy or tumor), ncRNA and its location, pcGene and its location, posterior probabilities of colocalization between the ncRNA and pcGene with the GWAS signal, and the colocalized SNP for each signal.

Table S5: GReX analysis results for ncRNAs and cancer risk. We provide the trait, tissue (breast or prostate), tissue state (healthy or tumor), ncRNA and its location, effect size, standard error, and Z-score of association. 